\title{
Considerations for Managing Internet of Things (IoT) Cybersecurity and Privacy Risks
}

\author{
Katie Boeckl \\ Michael Fagan \\ William Fisher \\ Naomi Lefkovitz \\ Katerina N. Megas \\ Ellen Nadeau \\ Danna Gabel O'Rourke \\ Ben Piccarreta \\ Karen Scarfone
}

This publication is available free of charge from:

https://doi.org/10.6028/NIST.IR.8228

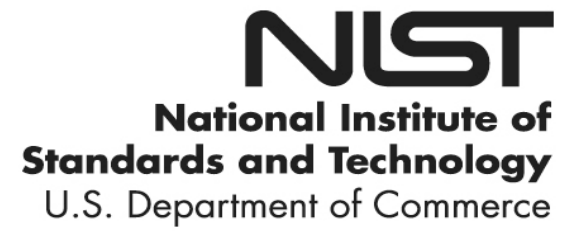




\section{Considerations for Managing Internet of Things (IoT) Cybersecurity and Privacy Risks}

\author{
Katie Boeckl \\ Michael Fagan \\ William Fisher \\ Naomi Lefkovitz \\ Katerina N. Megas \\ Ellen Nadeau \\ Ben Piccarreta* \\ Applied Cybersecurity Division \\ Information Technology Laboratory
}

Danna Gabel O'Rourke

Deloitte \& Touche LLP

Arlington, Virginia

Karen Scarfone

Scarfone Cybersecurity

Clifton, Virginia

*Former employee; all work for this publication was done while at NIST

This publication is available free of charge from: https://doi.org/10.6028/NIST.IR.8228

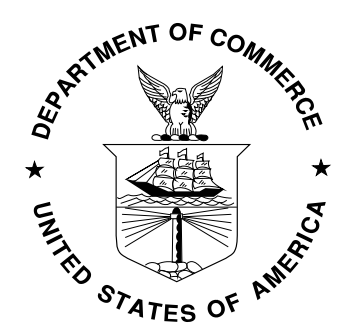

U.S. Department of Commerce Wilbur L. Ross, Jr., Secretary 


\title{
National Institute of Standards and Technology Interagency or Internal Report 8228 44 pages (June 2019)
}

This publication is available free of charge from: https://doi.org/10.6028/NIST.IR.8228

Certain commercial entities, equipment, or materials may be identified in this document in order to describe an experimental procedure or concept adequately. Such identification is not intended to imply recommendation or endorsement by NIST, nor is it intended to imply that the entities, materials, or equipment are necessarily the best available for the purpose.

There may be references in this publication to other publications currently under development by NIST in accordance with its assigned statutory responsibilities. The information in this publication, including concepts and methodologies, may be used by federal agencies even before the completion of such companion publications. Thus, until each publication is completed, current requirements, guidelines, and procedures, where they exist, remain operative. For planning and transition purposes, federal agencies may wish to closely follow the development of these new publications by NIST.

Organizations are encouraged to review all draft publications during public comment periods and provide feedback to NIST. Many NIST cybersecurity publications, other than the ones noted above, are available at https://csrc.nist.gov/publications.

\section{Comments on this publication may be submitted to:}

\author{
National Institute of Standards and Technology \\ Attn: Applied Cybersecurity Division, Information Technology Laboratory \\ 100 Bureau Drive (Mail Stop 2000) Gaithersburg, MD 20899-2000 \\ Email: iotsecurity@nist.gov
}

All comments are subject to release under the Freedom of Information Act (FOIA). 


\title{
Reports on Computer Systems Technology
}

The Information Technology Laboratory (ITL) at the National Institute of Standards and Technology (NIST) promotes the U.S. economy and public welfare by providing technical leadership for the Nation's measurement and standards infrastructure. ITL develops tests, test methods, reference data, proof of concept implementations, and technical analyses to advance the development and productive use of information technology. ITL's responsibilities include the development of management, administrative, technical, and physical standards and guidelines for the cost-effective security and privacy of other than national security-related information in federal information systems.

\begin{abstract}
The Internet of Things (IoT) is a rapidly evolving and expanding collection of diverse technologies that interact with the physical world. Many organizations are not necessarily aware of the large number of IoT devices they are already using and how IoT devices may affect cybersecurity and privacy risks differently than conventional information technology (IT) devices do. The purpose of this publication is to help federal agencies and other organizations better understand and manage the cybersecurity and privacy risks associated with their individual IoT devices throughout the devices' lifecycles. This publication is the introductory document providing the foundation for a planned series of publications on more specific aspects of this topic.
\end{abstract}

\section{Keywords}

cybersecurity risk; Internet of Things (IoT); privacy risk; risk management; risk mitigation. 


\section{Acknowledgments}

The authors wish to thank all contributors to this publication, including the participants in the workshops and other interactive sessions, the individuals and organizations from the public and private sectors who provided comments on the preliminary ideas, and the following individuals from NIST: Curt Barker, Matt Barrett, Barbara Cuthill, Donna Dodson, Jim Foti, Ned Goren, Nelson Hastings, Jody Jacobs, Suzanne Lightman, Jeff Marron, Vicky Pillitteri, Tim Polk, Matt Scholl, Eric Simmon, Matt Smith, Murugiah Souppaya, Jim St. Pierre, Kevin Stine, and David Wollman.

\section{Audience}

The primary audience for this publication is personnel at federal agencies with responsibilities related to managing cybersecurity and privacy risks for IoT devices, although personnel at other organizations may also find value in the content. Personnel within the following Workforce Categories and Specialty Areas from the National Initiative for Cybersecurity Education (NICE) Cybersecurity Workforce Framework [1] are most likely to find this publication of interest, as are their privacy counterparts:

- Securely Provision (SP): Risk Management (RSK), Systems Architecture (ARC), Systems Development (SYS)

- Operate and Maintain (OM): Data Administration (DTA), Network Services (NET), Systems Administration (ADM), Systems Analysis (ANA)

- Oversee and Govern (OV): Cybersecurity Management (MGT), Executive Cyber Leadership (EXL), Program/Project Management (PMA) and Acquisition

- Protect and Defend (PR): Cybersecurity Defense Analysis (CDA), Cybersecurity Defense Infrastructure Support (INF), Incident Response (CIR), Vulnerability Assessment and Management (VAM)

- Investigate (IN): Digital Forensics (FOR)

In addition, IoT device manufacturers and integrators may find this publication useful for understanding concerns regarding managing cybersecurity and privacy risks for IoT devices.

\section{Note to Readers}

Appendix A previously held examples of possible cybersecurity and privacy capabilities that organizations may want their IoT devices to have. That content has been removed from this publication and will be refined and released in a separate publication.

\section{Trademark Information}

All registered trademarks and trademarks belong to their respective organizations. 
Executive Summary

The Internet of Things (IoT) is a rapidly evolving and expanding collection of diverse technologies that interact with the physical world. IoT devices are an outcome of combining the worlds of information technology (IT) and operational technology (OT). Many IoT devices are the result of the convergence of cloud computing, mobile computing, embedded systems, big data, low-price hardware, and other technological advances. IoT devices can provide computing functionality, data storage, and network connectivity for equipment that previously lacked them, enabling new efficiencies and technological capabilities for the equipment, such as remote access for monitoring, configuration, and troubleshooting. IoT can also add the abilities to analyze data about the physical world and use the results to better inform decision making, alter the physical environment, and anticipate future events.

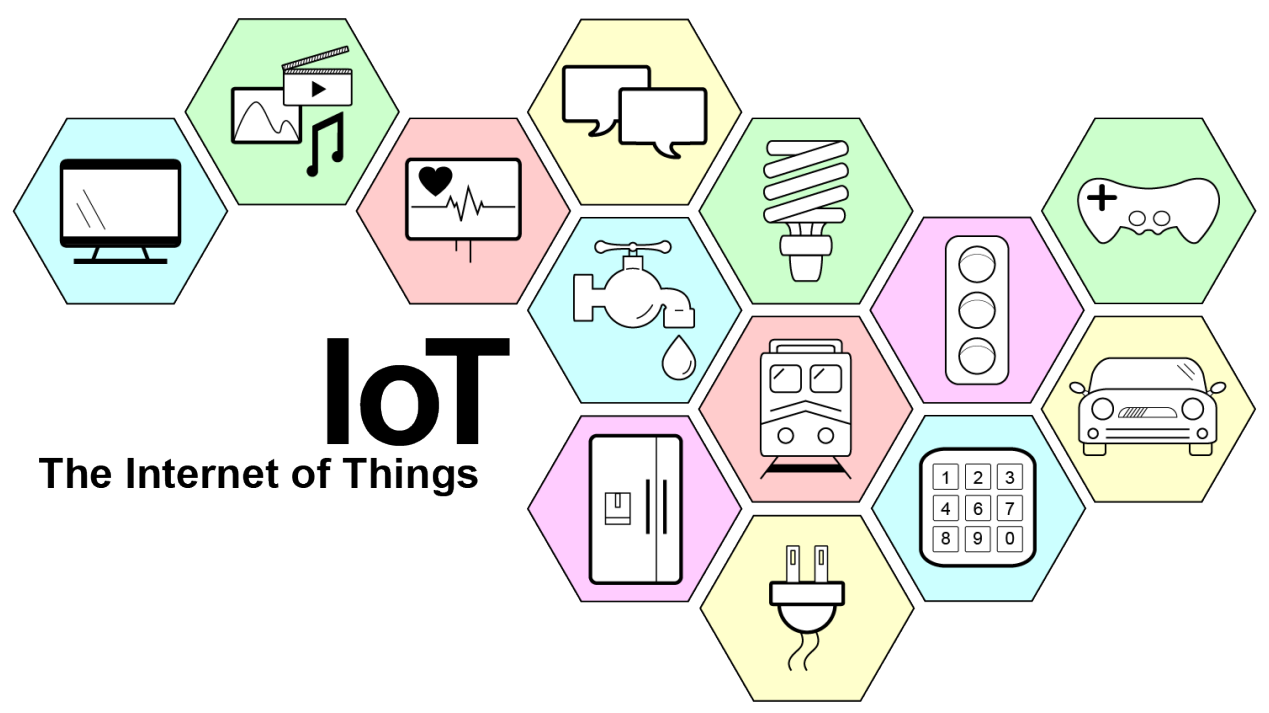

While the full scope of IoT is not precisely defined, it is clearly vast. Every sector has its own types of IoT devices, such as specialized hospital equipment in the healthcare sector and smart road technologies in the transportation sector, and there is a large number of enterprise IoT devices that every sector can use. Versions of nearly every consumer electronics device, many of which are also present in organizations' facilities, have become connected IoT devices - kitchen appliances, thermostats, home security cameras, door locks, light bulbs, and TVs. [2]

Many organizations are not necessarily aware they are using a large number of IoT devices. It is important that organizations understand their use of IoT because many IoT devices affect cybersecurity and privacy risks differently than conventional IT devices do. Once organizations are aware of their existing IoT usage and possible future usage, they need to understand how the characteristics of IoT affect managing cybersecurity and privacy risks, especially in terms of risk response - accepting, avoiding, mitigating, sharing, or transferring risk.

This publication identifies three high-level considerations that may affect the management of cybersecurity and privacy risks for IoT devices as compared to conventional IT devices:

1. Many IoT devices interact with the physical world in ways conventional IT devices usually do not. The potential impact of some IoT devices making changes to physical 
systems and thus affecting the physical world needs to be explicitly recognized and addressed from cybersecurity and privacy perspectives. Also, operational requirements for performance, reliability, resilience, and safety may be at odds with common cybersecurity and privacy practices for conventional IT devices.

2. Many IoT devices cannot be accessed, managed, or monitored in the same ways conventional IT devices can. This can necessitate doing tasks manually for large numbers of IoT devices, expanding staff knowledge and tools to include a much wider variety of IoT device software, and addressing risks with manufacturers and other third parties having remote access or control over IoT devices.

3. The availability, efficiency, and effectiveness of cybersecurity and privacy capabilities are often different for IoT devices than conventional IT devices. This means organizations may have to select, implement, and manage additional controls, as well as determine how to respond to risk when sufficient controls for mitigating risk are not available.

Cybersecurity and privacy risks for IoT devices can be thought of in terms of three high-level risk mitigation goals:

1. Protect device security. In other words, prevent a device from being used to conduct attacks, including participating in distributed denial of service (DDoS) attacks against other organizations, and eavesdropping on network traffic or compromising other devices on the same network segment. This goal applies to all IoT devices.

2. Protect data security. Protect the confidentiality, integrity, and/or availability of data (including personally identifiable information [PII]) collected by, stored on, processed by, or transmitted to or from the IoT device. This goal applies to each IoT device except those without any data that needs protection.

3. Protect individuals' privacy. Protect individuals' privacy impacted by PII processing beyond risks managed through device and data security protection. This goal applies to all IoT devices that process PII or that directly or indirectly impact individuals.

Each goal builds on the previous goal and does not replace it or negate the need for it. Meeting each of the risk mitigation goals involves addressing a set of risk mitigation areas. Each risk mitigation area defines an aspect of cybersecurity or privacy risk mitigation thought to be most significantly or unexpectedly affected for IoT by the risk considerations. For each risk mitigation area, there are one or more expectations organizations usually have for how conventional IT devices help mitigate cybersecurity and privacy risks for the area. Finally, there are one or more challenges that IoT devices may pose to each expectation. The figure below depicts the end result of these linkages, which is the identification of a structured set of potential challenges with mitigating cybersecurity and privacy risk for IoT devices that can each be traced back to the relevant risk considerations. 


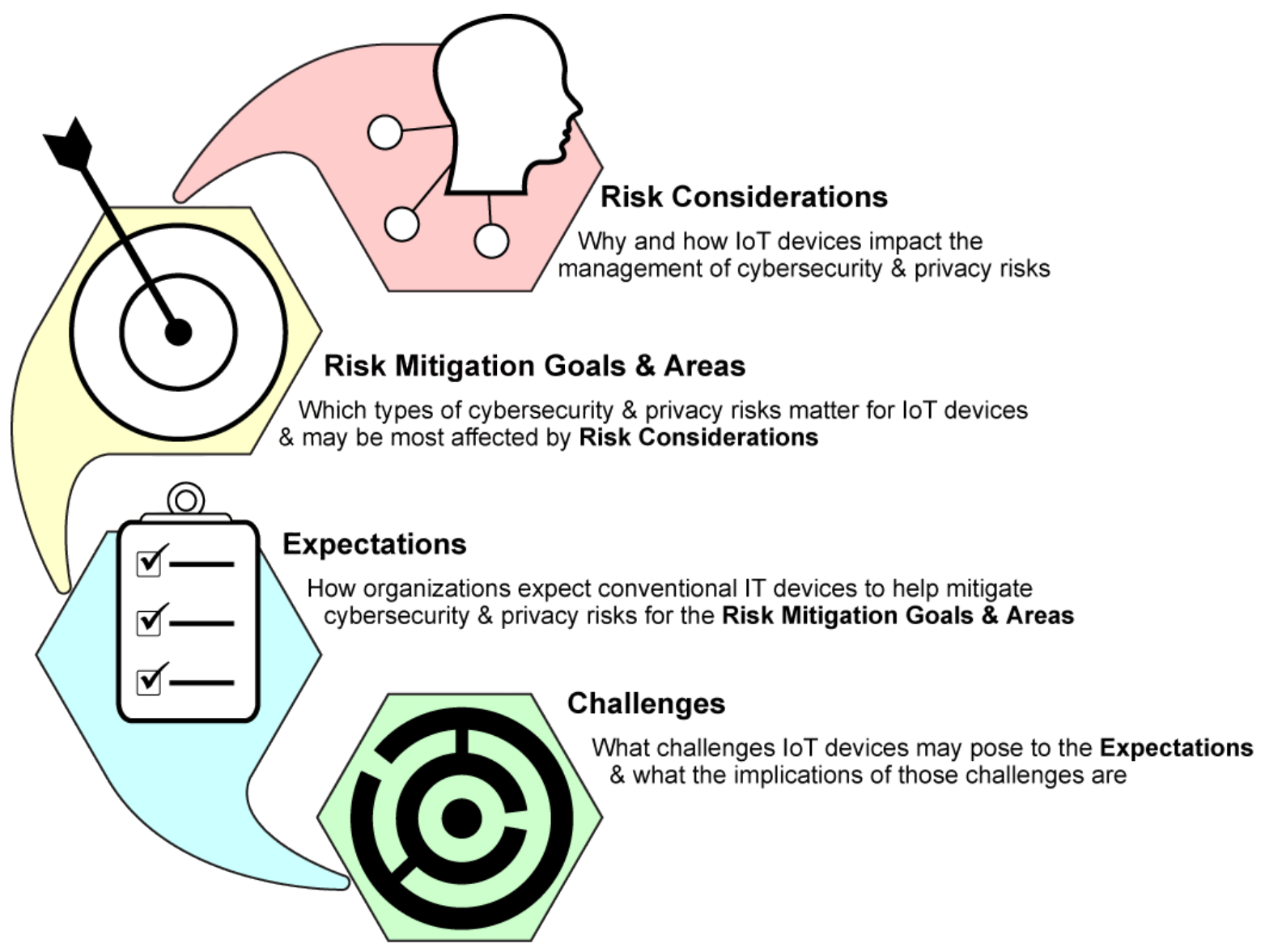

Organizations should ensure they are addressing the cybersecurity and privacy risk considerations and challenges throughout the IoT device lifecycle for the appropriate risk mitigation goals and areas. This publication provides the following recommendations for accomplishing this:

1. Understand the IoT device risk considerations and the challenges they may cause to mitigating cybersecurity and privacy risks for IoT devices in the appropriate risk mitigation areas.

2. Adjust organizational policies and processes to address the cybersecurity

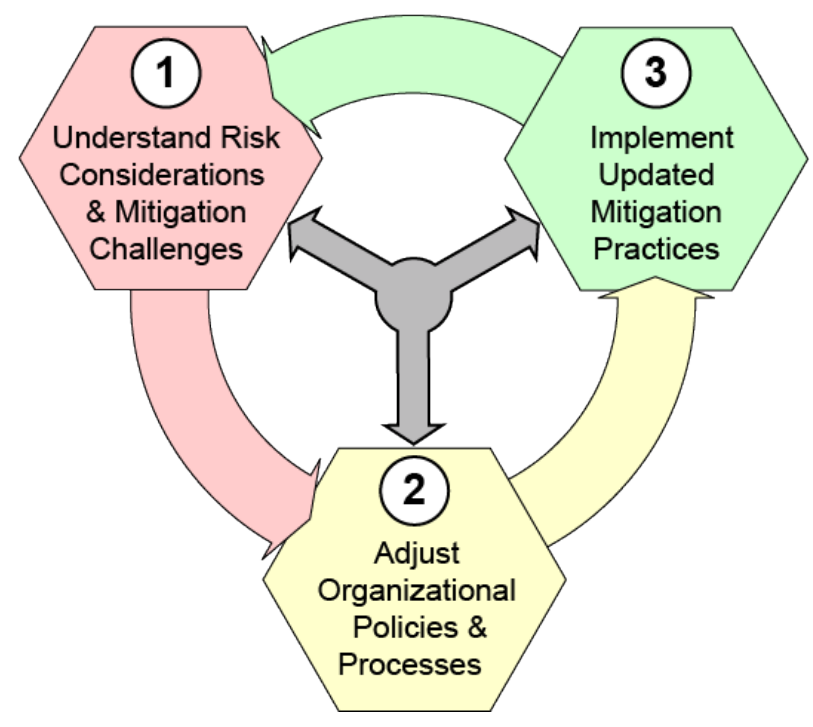
and privacy risk mitigation challenges throughout the IoT device lifecycle. This publication cites many examples of possible challenges, but each organization will need to customize these to take into account its mission requirements and other organizationspecific characteristics.

3. Implement updated mitigation practices for the organization's IoT devices as you would any other changes to practices. 


\section{Table of Contents}

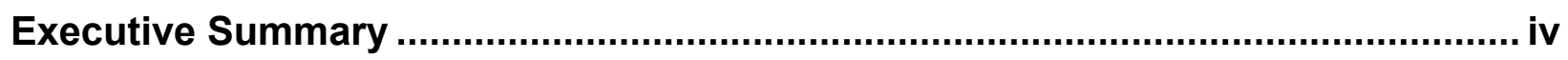

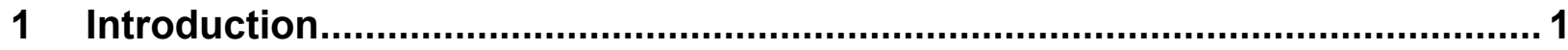

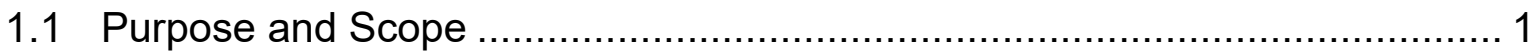

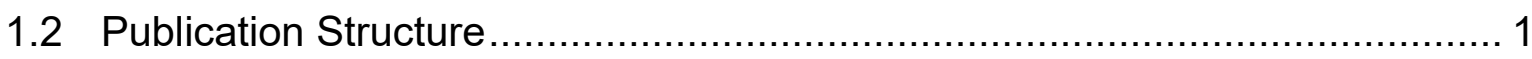

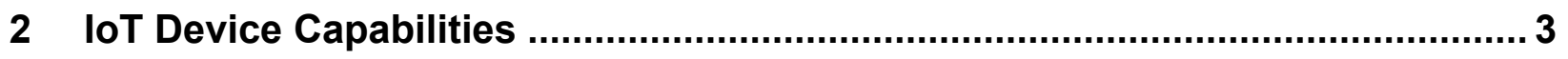

3 Cybersecurity and Privacy Risk Considerations ........................................... 5

3.1 Consideration 1: Device Interactions with the Physical World ...................... 6

3.2 Consideration 2: Device Access, Management, and Monitoring Features ...... 7

3.3 Consideration 3: Cybersecurity and Privacy Capability Availability, Efficiency,

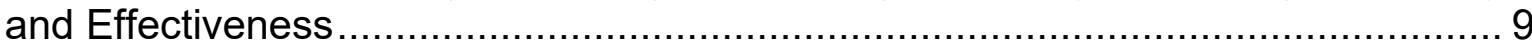

4 Challenges with Cybersecurity and Privacy Risk Mitigation for loT Devices . 11

4.1 Potential Challenges with Achieving Goal 1, Protect Device Security.......... 12

4.2 Potential Challenges with Achieving Goal 2, Protect Data Security ….......... 22

4.3 Potential Challenges with Achieving Goal 3, Protect Individuals' Privacy ..... 23

5 Recommendations for Addressing Cybersecurity and Privacy Risk Mitigation

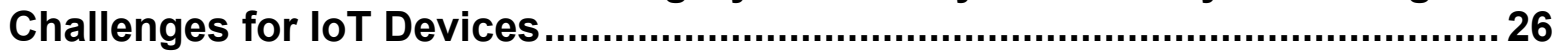

5.1 Adjusting Organizational Policies and Processes ..................................... 26

5.2 Implementing Updated Risk Mitigation Practices ....................................... 29

\section{List of Appendices}

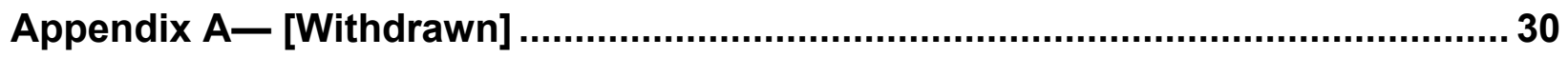

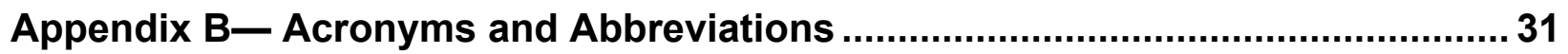

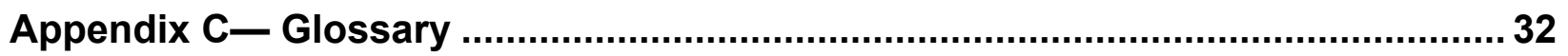

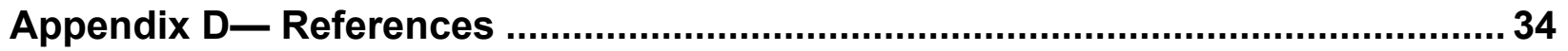

\section{List of Figures}

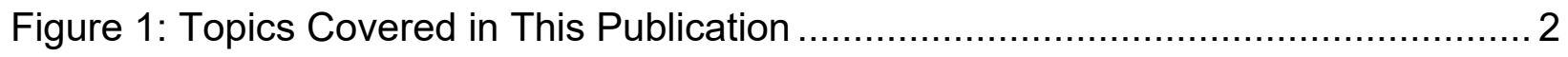

Figure 2: IoT Device Capabilities Potentially Affecting Cybersecurity and Privacy Risk.. 4

Figure 3: Relationship Between Cybersecurity and Privacy Risks ............................... 5

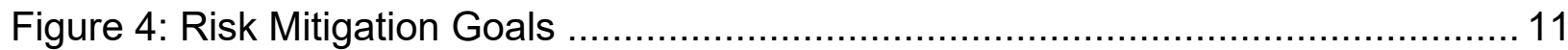

Figure 5: Relationships Among Section 3 and Section 4 Concepts ........................... 13

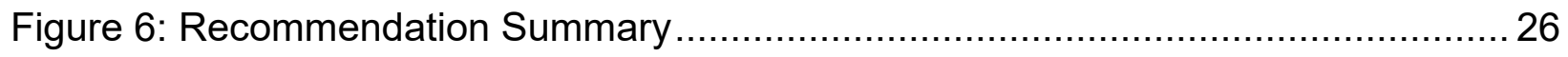




\section{List of Tables}

Table 1: Potential Challenges with Achieving Goal 1, Protect Device Security ............. 14

Table 2: Potential Challenges with Achieving Goal 2, Protect Data Security ................ 23

Table 3: Potential Challenges with Achieving Goal 3, Protect Individuals' Privacy ....... 24 


\section{Introduction}

\subsection{Purpose and Scope}

The purpose of this publication is to help organizations better understand and manage the cybersecurity and privacy risks associated with individual Internet of Things (IoT) devices throughout the devices' lifecycles. This publication emphasizes what makes managing these risks different for IoT devices in general, including consumer, enterprise, and industrial IoT devices, than conventional information technology (IT) devices. It omits all aspects of risk management that are largely the same for IoT and conventional IT, including all aspects of risk management beyond the IoT devices themselves, because these are already addressed by many other risk management publications.

The publication provides insights to inform organizations' risk management processes. After reading this publication, an organization should be able to improve the quality of its risk assessments for IoT devices and its response to the identified risk through the lens of cybersecurity and privacy. However, this does not mean cybersecurity and privacy risks for an IoT device can all be addressed within the device itself. Every IoT device operates within a broader IoT environment where it interacts with other IoT and non-IoT devices, cloud-based services, people, and other components.

For some IoT devices, additional types of risks, including safety, reliability, and resiliency, need to be managed simultaneously with cybersecurity and privacy risks because of the effects addressing one type of risk can have on others. Only cybersecurity and privacy risks are in scope for this publication. Readers who are particularly interested in better understanding other types of risks and their relationship to cybersecurity and privacy may benefit from reading NIST Special Publication (SP) 800-82 Revision 2, Guide to Industrial Control Systems (ICS) Security, which provides an operational technology (OT) perspective on cybersecurity and privacy. [3]

Readers do not need a technical understanding of IoT device composition and capabilities, but a basic understanding of cybersecurity and privacy principles is expected.

\subsection{Publication Structure}

The remainder of this publication is organized into the following major sections and appendices:

- Section 2 defines capabilities IoT devices can provide that are of primary interest in terms of potentially affecting cybersecurity and privacy risk.

- Section 3 describes considerations that may affect the management of cybersecurity and privacy risks for IoT devices.

- Section 4 explores how the risk considerations may affect mitigating cybersecurity and privacy risk for IoT devices. The section lists expectations for how these risks are mitigated in conventional IT environments, then explains how IoT presents challenges to those expectations and what the potential implications of those challenges are.

- Section 5 provides recommendations for organizations on how to address the cybersecurity and privacy risk mitigation challenges for their IoT devices. 
- Appendix A previously held examples of possible cybersecurity and privacy capabilities that organizations may want their IoT devices to have. That content has been removed from this publication and will be refined and released in a separate publication.

- Appendix B provides an acronym and abbreviation list.

- Appendix C contains a glossary of selected terms used in the publication.

- Appendix D lists the references for the publication.

Figure 1 depicts the topics covered in each section and subsection of this publication.

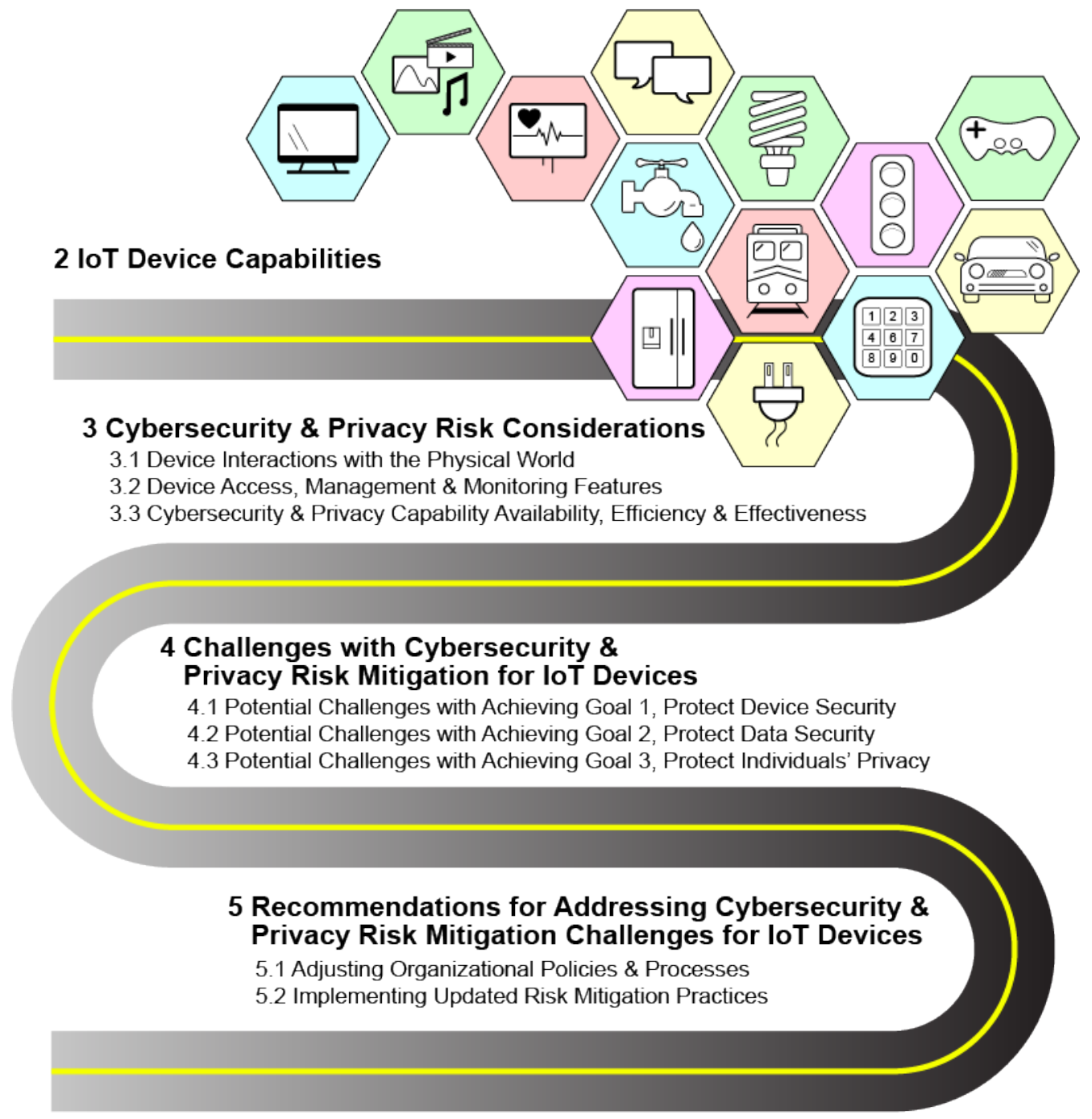

Figure 1: Topics Covered in This Publication 


\section{IoT Device Capabilities}

Each IoT device provides capabilities - features or functions - it can use on its own or in conjunction with other IoT and non-IoT devices to achieve one or more goals. This publication references the following types of capabilities IoT devices can provide that are of primary interest in terms of potentially affecting cybersecurity and privacy risk differently than conventional IT devices. This is not a comprehensive list of all possible IoT device capabilities.

- Transducer capabilities interact with the physical world and serve as the edge between digital and physical environments. Transducer capabilities provide the ability for computing devices to interact directly with physical entities of interest. Every IoT device has at least one transducer capability. The two types of transducer capabilities are:

- Sensing: the ability to provide an observation of an aspect of the physical world in the form of measurement data. Examples include temperature measurement, radiographic imaging, optical sensing, and audio sensing.

- Actuating: the ability to change something in the physical world. Examples of actuating capabilities include heating coils, cardiac electric shock delivery, electronic door locks, unmanned aerial vehicle operation, servo motors, and robotic arms.

- Interface capabilities enable device interactions (e.g., device-to-device communications, human-to-device communications). The types of interface capabilities are:

- Application interface: the ability for other computing devices to communicate with an IoT device through an IoT device application. An example of an application interface capability is an application programming interface (API).

- Human user interface: the ability for an IoT device and people to communicate directly with each other. Examples of human user interface capabilities include touch screens, haptic devices, microphones, cameras, and speakers.

- Network interface: the ability to interface with a communication network for the purpose of communicating data to or from an IoT device - in other words, to use a communication network. A network interface capability includes both hardware and software (e.g., a network interface card or chip and the software implementation of the networking protocol that uses the card or chip). Examples of network interface capabilities include Ethernet, Wi-Fi, Bluetooth, Long-Term Evolution (LTE), and ZigBee. Every IoT device has at least one enabled network interface capability and may have more than one.

- Supporting capabilities provide functionality that supports the other IoT capabilities. Examples are device management, cybersecurity, and privacy capabilities. [2]

Figure 2 summarizes these IoT device capabilities. 


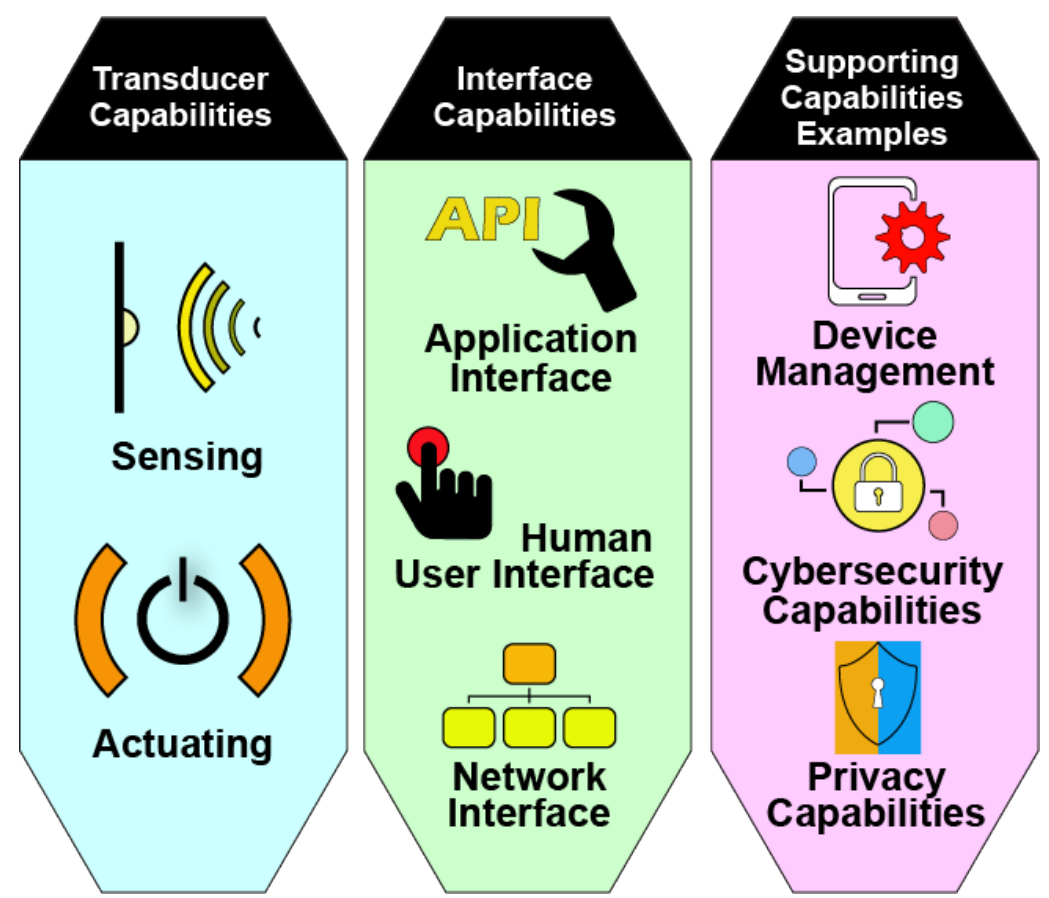

Figure 2: IoT Device Capabilities Potentially Affecting Cybersecurity and Privacy Risk 


\section{$3 \quad$ Cybersecurity and Privacy Risk Considerations}

Cybersecurity risk and privacy risk are related but distinct concepts. Risk is defined in NIST SP 800-37 Revision 2 as "a measure of the extent to which an entity is threatened by a potential circumstance or event, and typically is a function of: (i) the adverse impact, or magnitude of harm, that would arise if the circumstance or event occurs; and (ii) the likelihood of occurrence." [4] For cybersecurity, risk is about threats - the exploitation of vulnerabilities by threat actors to compromise device or data confidentiality, integrity, or availability. For privacy, risk is about problematic data actions - operations that process personally identifiable information (PII) through the information lifecycle to meet mission or business needs of an organization or "authorized" PII processing and, as a side effect, cause individuals to experience some type of problem(s). As Figure 3 depicts, privacy and cybersecurity risk overlap with respect to concerns about the cybersecurity of PII, but there are also privacy concerns without implications for cybersecurity, and cybersecurity concerns without implications for privacy. [5]

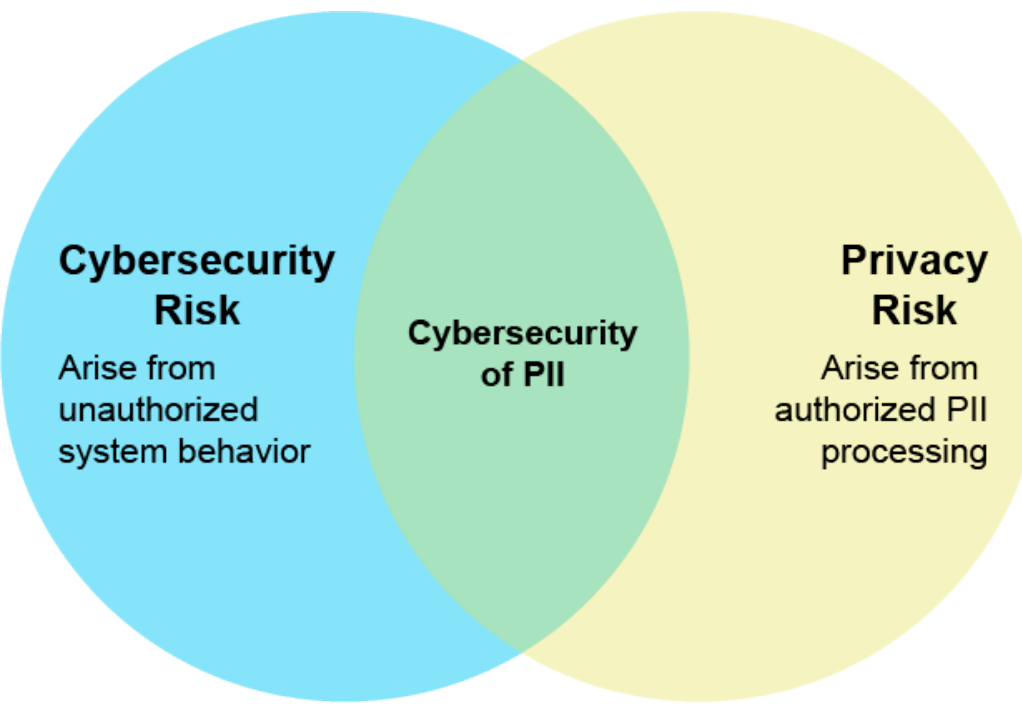

Figure 3: Relationship Between Cybersecurity and Privacy Risks

IoT devices generally face the same types of cybersecurity and privacy risks as conventional IT devices, though the prevalence and severity of such risks often differ. For example, data security risks are almost always a significant concern for conventional IT devices, but for some IoT devices, there may not be data security risks because they do not have any data that needs protection.

This section defines three cybersecurity and privacy risk considerations that may affect the management of cybersecurity and privacy risks for IoT devices. Organizations should ensure they are addressing these risk considerations throughout the lifecycle of their IoT devices. Section 4 provides more information on how these risk considerations may affect risk mitigation, and Section 5 provides recommendations for organizations on how to address the risk mitigation challenges. 


\subsection{Consideration 1: Device Interactions with the Physical World}

\section{Many IoT devices interact with the physical world in ways conventional IT devices usually do not.}

The interactions with the physical world that IoT devices enable may affect cybersecurity and privacy risks in several ways. Here are examples:

- IoT sensor data, representing measurements of the physical world, always has uncertainties associated with it. Effective management of IoT sensor data, including understanding uncertainties, is necessary to assess data quality and meaning so the organization can make decisions regarding the data's use and avoid introducing new risks. Without this, error rates may be unknown for the different contexts in which an IoT device might be used. ${ }^{1}$ Effective IoT sensor data management is important when mitigating physical attacks on sensor technology, such as attacks performed through wireless signals, that could cause sensors to produce false results.

- The ubiquity of IoT sensors in public and private environments can contribute to the aggregation and analysis of enormous amounts of data about individuals. These activities can be used to influence individuals' behavior or decision-making in ways they do not understand, or lead to information being revealed that individuals did not want revealed, including the re-identification of previously de-identified PII - and may be beyond the originally intended scope of the IoT device's operation.

- IoT devices with actuators have the ability to make changes to physical systems and thus affect the physical world. The potential impact of this needs to be explicitly recognized and addressed from cybersecurity and privacy perspectives. In a worst-case scenario, a compromise could allow an attacker to use an IoT device to endanger human safety, damage or destroy equipment and facilities, or cause major operational disruptions. Privacy concerns and related civil liberties concerns could arise through authorized changes to physical systems that could impact individuals' physical autonomy or behavior in personal and public spaces. For example, physical access controls, such as automated door locks, could be used to limit access to rooms or buildings with individuals inside, or environmental controls such as lighting or temperature could be used to influence individuals' movement in buildings.

- IoT network interfaces often enable remote access to physical systems that previously could only be accessed locally. Manufacturers, vendors, and other third parties may be able to use remote access to IoT devices for management, monitoring, maintenance, and troubleshooting purposes. This may put the physical systems accessible through the IoT devices at much greater risk of compromise. Further, these decentralized data processing functions can exacerbate some privacy risks, making it harder for individuals to understand how the IoT system is operating so that they can make informed decisions regarding the processing of their information and their interactions with the IoT system.

1 For more information on measurement uncertainty, see https://www.nist.gov/itl/sed/topic-areas/measurement-uncertainty. 
Another important aspect of IoT device interactions with the physical world is the operational requirements devices must meet in various environments and use cases. Many IoT devices must comply with stringent requirements for performance, reliability, resilience, safety, and other objectives. These requirements may be at odds with common cybersecurity and privacy practices for conventional IT. For example, practices such as automatic patching are generally considered essential for conventional IT, but these practices could have far greater negative impacts on some IoT devices with actuators, making critical services unavailable and endangering human safety. An organization might reasonably decide that patches should be installed at a date and time chosen by the organization with the appropriate staff onsite and ready to react immediately if a problem occurs. An organization might also reasonably decide to avoid patching certain IoT devices under normal circumstances and instead tightly restrict logical and physical access to them to prevent exploitation of unpatched vulnerabilities.

Another way to think of this is in terms of general cybersecurity objectives: confidentiality, integrity, and availability. For conventional IT devices, confidentiality often receives the most attention because of the value of data and the consequences of a breach of confidentiality. For many IoT devices, availability and integrity are more important than confidentiality because of the potential impact to the physical world. Imagine an IoT device that is critical for preventing damage to a facility. An attacker who can view the IoT device's stored or transmitted data might not gain any advantage or value from it, but an attacker who can alter the data might trigger a series of events that cause an incident.

\subsection{Consideration 2: Device Access, Management, and Monitoring Features}

\section{Many IoT devices cannot be accessed, managed, or monitored in the same ways conventional IT devices can.}

Conventional IT devices usually provide authorized people, processes, and devices with hardware and software access, management, and monitoring features. In other words, an authorized administrator, process, or device can directly access a conventional IT device's firmware, operating system, and applications, fully manage the device and its software throughout the device's lifecycle as needed, and monitor the internal characteristics and state of the device at all times. Authorized users can also access a restricted subset of the access, management, and monitoring features.

In contrast, many IoT devices are opaque, often referred to as "black boxes." They provide little or no visibility into their state and composition, including the identity of any external services and systems they interact with, and little or no access to and management of their software and configuration. The organization may not know what capabilities an IoT device can provide or is currently providing. In extreme cases, it may be difficult to determine if a black box product is actually an IoT device because of the lack of transparency.

Authorized people, processes, and devices may encounter one or more of the following challenges in accessing, managing, and monitoring IoT devices that affect cybersecurity and privacy risk: 
- Lack of management features. Administrators may not be able to fully manage an IoT device's firmware, operating system, and applications throughout the IoT device's lifecycle. Unavailable features may include the ability to acquire, verify the integrity of, install, configure, store, retrieve, execute, terminate, remove, replace, update, and patch software. In addition, an IoT device's software may be automatically reconfigured when an adverse event occurs, such as a power failure or a loss of network connectivity.

- Lack of interfaces. Some IoT devices lack application and/or human user interfaces for device use and management. When such interfaces do exist, they may not provide the functionality usually offered by conventional IT devices. An example is the challenge in notifying users about an IoT device's processing of their PII so they can provide meaningful consent to this processing. An additional issue is the lack of universally accepted standards for IoT application interfaces, including expressing and formatting data, issuing commands, and otherwise fostering interoperability between IoT devices.

- Difficulties with management at scale. Most IoT devices do not support standardized mechanisms for centralized management, and the sheer number of IoT devices to be managed may be overwhelming.

- Wide variety of software to manage. There is extensive variety in the software used by IoT devices, including firmware, standard and real-time operating systems, and applications. This significantly complicates software management throughout the IoT device lifecycle, affecting such areas as configuration and patch management.

- Differing lifespan expectations. A manufacturer may intend for a particular IoT device to only be used for a few years and then discarded. An organization purchasing that device might want to use it for a longer time, but the manufacturer may stop supporting the device (e.g., releasing patches for known vulnerabilities) either by choice or because of supply chain limitations (e.g., supplier no longer releases patches for a particular IoT device component). The problem of differing lifespan expectations is not new and is not specific to IoT, but it may be particularly important for some IoT devices because of safety, reliability, and other risks potentially involved in using devices past their intended lifespan.

- Unserviceable hardware. IoT device hardware may not be serviceable, meaning it cannot be repaired, customized, or inspected internally.

- Lack of inventory capabilities. IoT devices brought into an organization may not be inventoried, registered, and otherwise provisioned via the normal IT processes. This is especially true for types of devices that did not previously have networking capabilities.

- Heterogeneous ownership. There is often heterogeneous ownership of IoT devices. For example, an IoT device may transfer data to manufacturer-provided cloud-based service processing and storage. Data may also be sent to a cloud service to aggregate data from multiple IoT devices in a single location. These cloud services may have access to portions or all of the devices' data, or even access to and control of the devices themselves for monitoring, maintenance, and troubleshooting purposes. In some cases, only manufacturers have the authority to do maintenance; an organization attempting to install patches or do other maintenance tasks on an IoT device may void the warranty. Also, in IoT there may be little or no information available about device ownership, 
especially in black box IoT devices. This could exacerbate existing privacy redress difficulties because the lack of accountability limits individuals' abilities to locate the source of and correct or delete information about themselves, or to address other problems. Another concern with heterogeneous ownership is the effect on device reprovisioning — what data may still be available after transferring control of a device.

\subsection{Consideration 3: Cybersecurity and Privacy Capability Availability, Efficiency, and Effectiveness}

\section{The availability, efficiency, and effectiveness of cybersecurity and privacy capabilities are often different for IoT devices than conventional IT devices.}

For the purposes of this publication, built-in cybersecurity and privacy capabilities are called pre-market capabilities. Pre-market capabilities are integrated into IoT devices by the manufacturer or vendor before they are shipped to customer organizations. Post-market capabilities are those capabilities that organizations select, acquire, and deploy themselves in addition to pre-market capabilities. Pre-market and post-market cybersecurity and privacy capabilities are often different for IoT devices than conventional IT. The main reasons for this are:

- Many IoT devices do not or cannot support the range of cybersecurity and privacy capabilities typically built into conventional IT devices. For example, a "black box" IoT device may not log its cybersecurity and privacy events or may not give organizations access to its logs. If pre-market capabilities are available for IoT devices, they may be inadequate in terms of strength or performance-e.g., using strong encryption and mutual authentication to protect communications may cause unacceptable delays. ${ }^{2}$ Post-market capabilities cannot be installed onto many IoT devices. Also, existing pre-market and post-market capabilities may not be able to scale to meet the needs of IoT-for example, an existing network-based cybersecurity appliance for conventional IT devices may not be able to also process the volume of network traffic and generated data from a large number of IoT devices.

- The level of effort needed to manage, monitor, and maintain pre-market capabilities on each IoT device may be excessive. Especially when IoT devices do not support centralized management, it may be more efficient to implement and use centralized postmarket capabilities that help protect numerous IoT devices instead of trying to achieve the equivalent level of protection on each individual IoT device. One example is having a single network-based IoT gateway or IoT security gateway protecting many IoT devices instead of having to design, manage, and maintain a unique set of protection capabilities within each IoT device.

- Some post-market capabilities for conventional IT, such as network-based intrusion prevention systems, antimalware servers, and firewalls, may not be as effective at

2 For more information on low-resource computing devices, see Bormann C, Ersue M, Keranen A (2014) Terminology for Constrained-Node Networks. (Internet Engineering Task Force (IETF)), Request for Comments (RFC) 7228.

https://doi.org/10.17487/RFC7228. 
protecting IoT devices as they are at protecting conventional IT. IoT devices often use protocols that cybersecurity and privacy controls for conventional IT cannot understand and analyze. Also, IoT devices may communicate directly with each other, such as through point-to-point wireless communication, instead of using a monitored infrastructure network.

An IoT device may not need some of the cybersecurity and privacy capabilities conventional IT devices rely on - an example is an IoT device without data storage capabilities not needing to protect data at rest. An IoT device may also need additional capabilities that most conventional IT devices do not use, especially if the IoT device enables new interactions with the physical world. 


\section{$4 \quad$ Challenges with Cybersecurity and Privacy Risk Mitigation for loT Devices}

Cybersecurity and privacy risks for IoT devices can be thought of in terms of three high-level risk mitigation goals, as shown in Figure 4:

1. Protect device security. In other words, prevent a device from being used to conduct attacks, including participating in distributed denial of service (DDoS) attacks against other organizations, and eavesdropping on network traffic or compromising other devices on the same network segment. This goal applies to all IoT devices.

2. Protect data security. Protect the confidentiality, integrity, and/or availability of data (including PII) collected by, stored on, processed by, or transmitted to or from the IoT device. This goal applies to each IoT device except those without any data that needs protection.

3. Protect individuals' privacy. Protect individuals' privacy impacted by PII processing beyond risks managed through device and data security protection. This goal applies to all IoT devices that process PII or that directly or indirectly impact individuals.

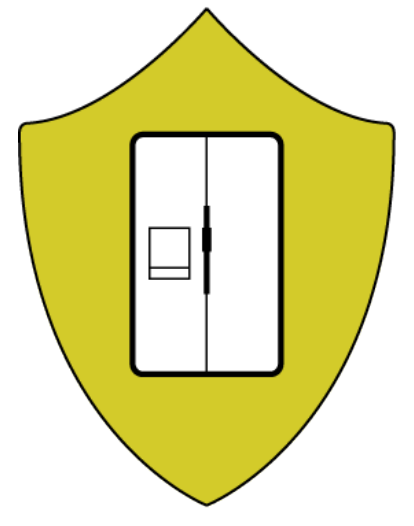

Protect Device Security

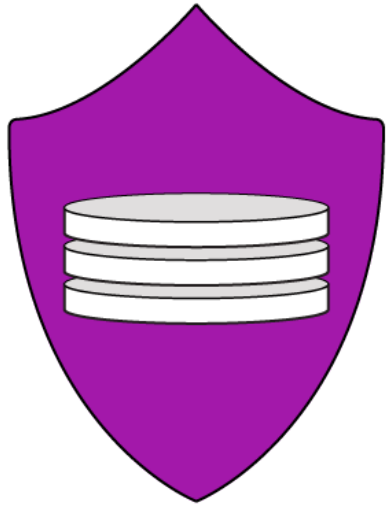

Protect Data Security

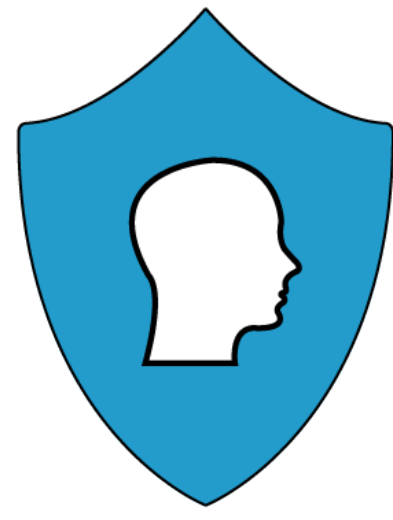

Protect Individuals' Privacy

Figure 4: Risk Mitigation Goals

Each goal builds on the previous goal and does not replace it or negate the need for it. Meeting each of the risk mitigation goals involves addressing a set of risk mitigation areas, which are defined below. Each risk mitigation area defines an aspect of cybersecurity or privacy risk mitigation thought to be most significantly or unexpectedly affected for IoT by the risk considerations defined in Section 3.

Risk mitigation areas for Goal 1, Protect Device Security:

- Asset Management: Maintain a current, accurate inventory of all IoT devices and their relevant characteristics throughout the devices' lifecycles in order to use that information for cybersecurity and privacy risk management purposes.

- Vulnerability Management: Identify and eliminate known vulnerabilities in IoT device software and firmware in order to reduce the likelihood and ease of exploitation and compromise. 
- Access Management: Prevent unauthorized and improper physical and logical access to, usage of, and administration of IoT devices by people, processes, and other computing devices.

- Device Security Incident Detection: Monitor and analyze IoT device activity for signs of incidents involving device security.

Risk mitigation areas for Goal 2, Protect Data Security:

- Data Protection: Prevent access to and tampering with data at rest or in transit that might expose sensitive information or allow manipulation or disruption of IoT device operations.

- Data Security Incident Detection: Monitor and analyze IoT device activity for signs of incidents involving data security.

Risk mitigation areas for Goal 3, Protect Individuals’ Privacy:

- Information Flow Management: Maintain a current, accurate mapping of the information lifecycle of PII, including the type of data action, the elements of PII being processed by the data action, the party doing the processing, and any additional relevant contextual factors about the processing to use for privacy risk management purposes.

- PII Processing Permissions Management: Maintain permissions for PII processing to prevent unpermitted PII processing.

- Informed Decision Making: Enable individuals to understand the effects of PII processing and interactions with the device, participate in decision-making about the PII processing or interactions, and resolve problems.

- Disassociated Data Management: Identify authorized PII processing and determine how PII may be minimized or disassociated from individuals and IoT devices.

- Privacy Breach Detection: Monitor and analyze IoT device activity for signs of breaches involving individuals' privacy.

Sections 4.1, 4.2, and 4.3 examine how the risk considerations introduce challenges for cybersecurity and privacy risk managers with meeting each of the three risk mitigation goals for an organization's IoT devices - in other words, how mitigation may differ for IoT versus conventional IT. Section 5 provides recommendations on how organizations should address these challenges.

\subsection{Potential Challenges with Achieving Goal 1, Protect Device Security}

Figure 5 shows the relationships among the Section 3 and Section 4 concepts. Section 3 defines the three risk considerations, which explain why and how IoT devices impact the management of cybersecurity and privacy risks. Next, the Section 4 introduction defines the risk mitigation goals and areas, which specify which types of cybersecurity and privacy risks matter for IoT devices and may be most affected by the risk considerations. The rest of Section 4 lists expectations, which are how organizations expect conventional IT devices to help mitigate cybersecurity and 
privacy risks for the risk mitigation goals and areas, and the challenges IoT devices may pose to those expectations, along with the implications of those challenges. The end result of these linkages is the identification of a structured set of potential challenges for mitigating cybersecurity and privacy risk for IoT devices that can each be traced back to the relevant risk considerations.

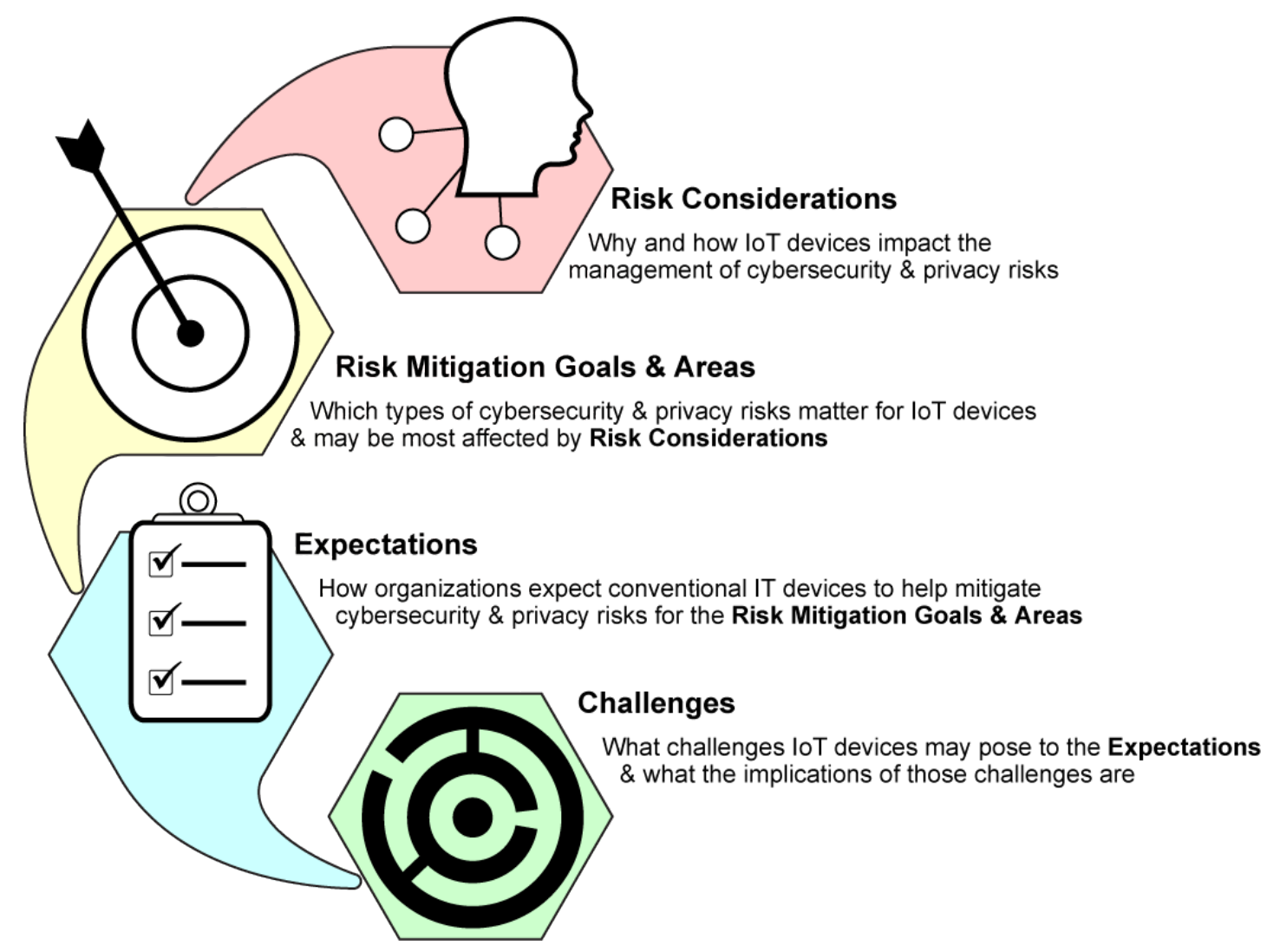

Figure 5: Relationships Among Section 3 and Section 4 Concepts

Many readers may not need to use the information at all the levels of detail depicted in Figure 5, and some readers may only need the information at one level, such as the list of challenges. This document includes all the levels in order to explain the basis for identifying these particular challenges as being potentially significant for IoT devices. Also, some readers may be able to use all levels to inform their risk management efforts.

Table 1 lists common expectations for the pre-market capabilities of conventional IT devices that are often used to help mitigate their device security risk. Although these expectations are not always true for conventional IT devices, they are usually true and have greatly influenced common device security practices for conventional IT devices. For each expectation, Table 1 defines one or more potential challenges individual IoT devices may pose to the expectation. Each challenge has its own row in the table:

- First column: a brief statement of the challenge, with each challenge uniquely numbered to make it easy to reference, and the numbers of the risk considerations from Section 3 that cause the challenge. 
- Second column: examples of draft NIST SP 800-53 Revision 5 [7] controls that might be negatively affected to some extent for some individual IoT devices.

- Third column: the potential implications for the organization if a substantial number of IoT devices are affected by the challenge.

- Fourth column: examples of Cybersecurity Framework Subcategories [6] that might be negatively affected to some extent by the implications.

The tables in this section do not define or imply equivalence between the NIST SP 800-53 controls and the Cybersecurity Framework Subcategories in each row. For example, in many cases, a challenge affects one aspect of the SP 800-53 controls and a different aspect of the Cybersecurity Framework Subcategories. Additionally, IoT devices not meeting traditional expectations could be a positive for risk mitigation since these limitations could pose less risk than when the more robust capability or function is present as per expectation. The table does not define these considerations, but instead aims to help cybersecurity and privacy risk managers understand how IoT devices may or may not fit into their existing mitigations and/or impact how cybersecurity and privacy outcomes for their organization are currently achieved.

Table 1: Potential Challenges with Achieving Goal 1, Protect Device Security

\begin{tabular}{|c|c|c|c|}
\hline $\begin{array}{l}\text { Challenges for Individual } \\
\text { loT Devices, and } \\
\text { Risk Considerations } \\
\text { Causing the Challenges }\end{array}$ & $\begin{array}{c}\text { Affected Draft NIST SP } \\
\text { 800-53 Revision } 5 \\
\text { Controls }\end{array}$ & $\begin{array}{l}\text { Implications for the } \\
\text { Organization }\end{array}$ & $\begin{array}{l}\text { Affected Cybersecurity } \\
\text { Framework Subcategories }\end{array}$ \\
\hline \multicolumn{4}{|l|}{ Asset Management } \\
\hline \multicolumn{4}{|c|}{ Expectation 1: The device has a built-in unique identifier. } \\
\hline $\begin{array}{l}\text { 1. The loT device may not } \\
\text { have a unique identifier } \\
\text { that the organization's } \\
\text { asset management } \\
\text { system can access or } \\
\text { understand. } \\
\text { Risk Consideration } 2\end{array}$ & $\begin{array}{l}\text { - CM-8, System } \\
\text { Component Inventory }\end{array}$ & $\begin{array}{l}\text { - May complicate } \\
\text { device management, } \\
\text { including remote } \\
\text { access and } \\
\text { vulnerability } \\
\text { management. }\end{array}$ & $\begin{array}{l}\text { - ID.AM-1: Physical devices } \\
\text { and systems within the } \\
\text { organization are inventoried }\end{array}$ \\
\hline \multicolumn{4}{|c|}{ Expectation 2: The device can interface with enterprise asset management systems. } \\
\hline $\begin{array}{l}\text { 2. The loT device may not } \\
\text { be able to participate in } \\
\text { a centralized asset } \\
\text { management system. } \\
\text { Risk Consideration } 2\end{array}$ & $\begin{array}{l}\text { - CM-8, System } \\
\text { Component Inventory }\end{array}$ & $\begin{array}{l}\text { - May have to use } \\
\text { multiple asset } \\
\text { management } \\
\text { systems. } \\
\text { - May have to perform } \\
\text { asset management } \\
\text { tasks manually. }\end{array}$ & $\begin{array}{l}\text { - ID.AM-1: Physical devices } \\
\text { and systems within the } \\
\text { organization are inventoried } \\
\text { - ID.AM-2: Software platforms } \\
\text { and applications within the } \\
\text { organization are inventoried } \\
\text { - PR.DS-3: Assets are } \\
\text { formally managed } \\
\text { throughout removal, } \\
\text { transfers, and disposition }\end{array}$ \\
\hline
\end{tabular}




\begin{tabular}{|c|c|c|c|}
\hline $\begin{array}{l}\text { Challenges for Individual } \\
\text { loT Devices, and } \\
\text { Risk Considerations } \\
\text { Causing the Challenges }\end{array}$ & $\begin{array}{c}\text { Affected Draft NIST SP } \\
\text { 800-53 Revision } 5 \\
\text { Controls }\end{array}$ & $\begin{array}{l}\text { Implications for the } \\
\text { Organization }\end{array}$ & $\begin{array}{c}\text { Affected Cybersecurity } \\
\text { Framework Subcategories }\end{array}$ \\
\hline $\begin{array}{l}\text { 3. The loT device may not } \\
\text { be directly connected to } \\
\text { any of the } \\
\text { organization's } \\
\text { networks. } \\
\text { Risk Consideration } 2\end{array}$ & $\begin{array}{l}\text { - CM-8, System } \\
\text { Component Inventory }\end{array}$ & $\begin{array}{l}\text { - May have to use a } \\
\text { separate asset } \\
\text { management system } \\
\text { or service, or manual } \\
\text { asset management } \\
\text { processes, for } \\
\text { external loT devices. }\end{array}$ & $\begin{array}{l}\text { - ID.AM-1: Physical devices } \\
\text { and systems within the } \\
\text { organization are inventoried } \\
\text { - ID.AM-2: Software platforms } \\
\text { and applications within the } \\
\text { organization are inventoried } \\
\text { - PR.DS-3: Assets are } \\
\text { formally managed } \\
\text { throughout removal, } \\
\text { transfers, and disposition }\end{array}$ \\
\hline $\begin{array}{l}\text { 4. The loT device may be } \\
\text { a black box that } \\
\text { provides little or no } \\
\text { information on its } \\
\text { hardware, software, } \\
\text { and firmware. } \\
\text { Risk Consideration } 2\end{array}$ & $\begin{array}{l}\text { - CM-8, System } \\
\text { Component Inventory }\end{array}$ & $\begin{array}{l}\text { - May complicate all } \\
\text { aspects of device } \\
\text { management and } \\
\text { risk management. }\end{array}$ & $\begin{array}{l}\text { - ID.AM-1: Physical devices } \\
\text { and systems within the } \\
\text { organization are inventoried } \\
\text { - ID.AM-2: Software platforms } \\
\text { and applications within the } \\
\text { organization are inventoried } \\
\text { - ID.AM-4: External } \\
\text { information systems are } \\
\text { catalogued }\end{array}$ \\
\hline
\end{tabular}

Expectation 4: The device or the device's manufacturer can inform the organization of all external software and services the device uses, such as software running on or dynamically downloaded from the cloud.

\begin{tabular}{|c|c|c|c|}
\hline $\begin{array}{l}\text { 5. Not all of the loT } \\
\text { device's external } \\
\text { dependencies may be } \\
\text { revealed. } \\
\text { Risk Consideration } 2\end{array}$ & $\begin{array}{l}\text { - AC-20, Use of } \\
\text { External Systems }\end{array}$ & $\begin{array}{l}\text { - Cannot manage risk } \\
\text { for the external } \\
\text { software and } \\
\text { services. }\end{array}$ & $\begin{array}{l}\text { - DE.CM-8: Vulnerability } \\
\text { scans are performed } \\
\text { - PR.IP-1: A baseline } \\
\text { configuration of information } \\
\text { technology/industrial control } \\
\text { systems is created and } \\
\text { maintained incorporating } \\
\text { security principles (e.g. } \\
\text { concept of least } \\
\text { functionality) } \\
\text { - PR.PT-3: The principle of } \\
\text { least functionality is } \\
\text { incorporated by configuring } \\
\text { systems to provide only } \\
\text { essential capabilities }\end{array}$ \\
\hline \multicolumn{4}{|l|}{ Vulnerability Management } \\
\hline \multicolumn{4}{|c|}{$\begin{array}{l}\text { Expectation 5: The manufacturer will provide patches or upgrades for all software and firmware throughout each } \\
\text { device's lifespan. }\end{array}$} \\
\hline $\begin{array}{l}\text { 6. The manufacturer may } \\
\text { not release patches or } \\
\text { upgrades for the loT } \\
\text { device. } \\
\text { Risk Consideration } 3\end{array}$ & $\begin{array}{l}\text { - Sl-2, Flaw } \\
\text { Remediation }\end{array}$ & $\begin{array}{l}\text { - Cannot remove } \\
\text { known vulnerabilities. }\end{array}$ & $\begin{array}{l}\text { PR.IP-1: A baseline } \\
\text { configuration of information } \\
\text { technology/industrial control } \\
\text { systems is created and } \\
\text { maintained incorporating } \\
\text { security principles (e.g. } \\
\text { concept of least } \\
\text { functionality) }\end{array}$ \\
\hline
\end{tabular}




\begin{tabular}{|c|c|c|c|}
\hline $\begin{array}{c}\text { Challenges for Individual } \\
\text { loT Devices, and } \\
\text { Risk Considerations } \\
\text { Causing the Challenges }\end{array}$ & $\begin{array}{c}\text { Affected Draft NIST SP } \\
\text { 800-53 Revision } 5 \\
\text { Controls }\end{array}$ & $\begin{array}{l}\text { Implications for the } \\
\text { Organization }\end{array}$ & $\begin{array}{l}\text { Affected Cybersecurity } \\
\text { Framework Subcategories }\end{array}$ \\
\hline $\begin{array}{l}\text { 7. The manufacturer may } \\
\text { stop releasing patches } \\
\text { and upgrades for the } \\
\text { loT device while it is still } \\
\text { in use. } \\
\text { Risk Consideration } 3\end{array}$ & $\begin{array}{l}\text { - Sl-2, Flaw } \\
\text { Remediation }\end{array}$ & $\begin{array}{l}\text { - May not be able to } \\
\text { remove known } \\
\text { vulnerabilities in the } \\
\text { future. }\end{array}$ & $\begin{array}{l}\text { PR.IP-1: A baseline } \\
\text { configuration of information } \\
\text { technology/industrial control } \\
\text { systems is created and } \\
\text { maintained incorporating } \\
\text { security principles (e.g. } \\
\text { concept of least } \\
\text { functionality) }\end{array}$ \\
\hline \multicolumn{4}{|c|}{$\begin{array}{l}\text { Expectation 6: The device either has its own secure built-in patch, upgrade, and configuration management } \\
\text { capabilities, or can interface with enterprise vulnerability management systems with such capabilities. }\end{array}$} \\
\hline $\begin{array}{l}\text { 8. The loT device may not } \\
\text { be capable of having its } \\
\text { software patched or } \\
\text { upgraded. } \\
\text { Risk Considerations } 2 \\
\text { and } 3\end{array}$ & $\begin{array}{l}\text { SI-2, Flaw } \\
\text { Remediation }\end{array}$ & $\begin{array}{l}\text { Cannot remove } \\
\text { known vulnerabilities. }\end{array}$ & $\begin{array}{l}\text { - PR.IP-1: A baseline } \\
\text { configuration of information } \\
\text { technology/industrial control } \\
\text { systems is created and } \\
\text { maintained incorporating } \\
\text { security principles (e.g. } \\
\text { concept of least } \\
\text { functionality) }\end{array}$ \\
\hline $\begin{array}{l}\text { 9. It may be too risky to } \\
\text { install patches or } \\
\text { upgrades or to make } \\
\text { configuration changes } \\
\text { without extensive } \\
\text { testing and preparation } \\
\text { first, and implementing } \\
\text { changes may require } \\
\text { operational outages or } \\
\text { inadvertently cause } \\
\text { outages. } \\
\text { Risk Consideration } 1\end{array}$ & $\begin{array}{l}\text { - CM-3, Configuration } \\
\text { Change Control } \\
\text { - CM-6, Configuration } \\
\text { Settings } \\
\text { - SI-2, Flaw } \\
\text { Remediation }\end{array}$ & $\begin{array}{l}\text { May be significant } \\
\text { delays in removing } \\
\text { known vulnerabilities. }\end{array}$ & $\begin{array}{l}\text { PR.IP-1: A baseline } \\
\text { configuration of information } \\
\text { technology/industrial control } \\
\text { systems is created and } \\
\text { maintained incorporating } \\
\text { security principles (e.g. } \\
\text { concept of least } \\
\text { functionality) }\end{array}$ \\
\hline $\begin{array}{l}\text { 10. The loT device may } \\
\text { not be able to } \\
\text { participate in a } \\
\text { centralized } \\
\text { vulnerability } \\
\text { management system. } \\
\text { Risk Consideration } 2\end{array}$ & $\begin{array}{l}\text { - CM-3, Configuration } \\
\text { Change Control } \\
\text { - SI-2, Flaw } \\
\text { Remediation }\end{array}$ & $\begin{array}{l}\text { - May have to use } \\
\text { numerous } \\
\text { vulnerability } \\
\text { management } \\
\text { systems instead of } \\
\text { one. } \\
\text { - May have to perform } \\
\text { vulnerability } \\
\text { management tasks } \\
\text { manually and } \\
\text { periodically (e.g., } \\
\text { manually install } \\
\text { patches, manually } \\
\text { check for software } \\
\text { configuration errors). }\end{array}$ & $\begin{array}{l}\text { PR.IP-1: A baseline } \\
\text { configuration of information } \\
\text { technology/industrial control } \\
\text { systems is created and } \\
\text { maintained incorporating } \\
\text { security principles (e.g. } \\
\text { concept of least } \\
\text { functionality) }\end{array}$ \\
\hline
\end{tabular}




\begin{tabular}{|c|c|c|c|}
\hline $\begin{array}{l}\text { Challenges for Individual } \\
\text { loT Devices, and } \\
\text { Risk Considerations } \\
\text { Causing the Challenges }\end{array}$ & $\begin{array}{c}\text { Affected Draft NIST SP } \\
\text { 800-53 Revision } 5 \\
\text { Controls }\end{array}$ & $\begin{array}{l}\text { Implications for the } \\
\text { Organization }\end{array}$ & $\begin{array}{l}\text { Affected Cybersecurity } \\
\text { Framework Subcategories }\end{array}$ \\
\hline $\begin{array}{l}\text { 11. The loT device may } \\
\text { not offer the ability to } \\
\text { change the software } \\
\text { configuration or may } \\
\text { not offer the features } \\
\text { organizations want. } \\
\text { Risk Consideration } 2\end{array}$ & $\begin{array}{l}\text { - CM-2, Baseline } \\
\text { Configuration } \\
\text { - CM-3, Configuration } \\
\text { Change Control } \\
\text { - CM-6, Configuration } \\
\text { Settings } \\
\text { - CM-7, Least } \\
\text { Functionality } \\
\text { - SC-42, Sensor } \\
\text { Capability and Data }\end{array}$ & $\begin{array}{l}\text { - Cannot remove } \\
\text { known vulnerabilities. } \\
\text { - Cannot achieve the } \\
\text { principle of least } \\
\text { functionality by } \\
\text { disabling unneeded } \\
\text { services, functions. } \\
\text { - Cannot restrict } \\
\text { sensor activation and } \\
\text { usage. }\end{array}$ & $\begin{array}{l}\text { - PR.IP-1: A baseline } \\
\text { configuration of information } \\
\text { technology/industrial control } \\
\text { systems is created and } \\
\text { maintained incorporating } \\
\text { security principles (e.g. } \\
\text { concept of least } \\
\text { functionality) } \\
\text { - PR.IP-3: Configuration } \\
\text { change control processes } \\
\text { are in place } \\
\text { - PR.PT-3: The principle of } \\
\text { least functionality is } \\
\text { incorporated by configuring } \\
\text { systems to provide only } \\
\text { essential capabilities }\end{array}$ \\
\hline $\begin{array}{l}\text { Expectation 7: The device } \\
\text { identification and reporting }\end{array}$ & ithor connouts the ropof, & & ides built-in vulnerability \\
\hline $\begin{array}{l}\text { 12. There may not be a } \\
\text { vulnerability scanner } \\
\text { that can run on or } \\
\text { against the loT device. } \\
\text { Risk Consideration } 3\end{array}$ & $\begin{array}{l}\text { - RA-5, Vulnerability } \\
\text { Scanning }\end{array}$ & $\begin{array}{l}\text { - Cannot automatically } \\
\text { identify known } \\
\text { vulnerabilities. }\end{array}$ & $\begin{array}{l}\text { - DE.CM-8: Vulnerability } \\
\text { scans are performed }\end{array}$ \\
\hline $\begin{array}{l}\text { 13. The loT device may } \\
\text { not offer any built-in } \\
\text { capabilities to identify } \\
\text { and report on known } \\
\text { vulnerabilities. } \\
\text { Risk Consideration } 3\end{array}$ & $\begin{array}{l}\text { - RA-5, Vulnerability } \\
\text { Scanning }\end{array}$ & $\begin{array}{l}\text { - Cannot automatically } \\
\text { identify known } \\
\text { vulnerabilities. }\end{array}$ & $\begin{array}{l}\text { - DE.CM-8: Vulnerability } \\
\text { scans are performed }\end{array}$ \\
\hline \multicolumn{4}{|l|}{ Access Management } \\
\hline Expectation 8: The devi & & & it. \\
\hline $\begin{array}{l}\text { 14. The loT device may } \\
\text { not support any use of } \\
\text { identifiers. } \\
\text { Risk Considerations } 2 \\
\text { and } 3\end{array}$ & $\begin{array}{l}\text { - IA-2, Identification and } \\
\text { Authentication } \\
\text { (Organizational Users) } \\
\text { - IA-3, Device } \\
\text { Identification and } \\
\text { Authentication } \\
\text { - IA-4, Identifier } \\
\text { Management } \\
\text { - IA-8, Identification and } \\
\text { Authentication (Non- } \\
\text { Organizational Users) } \\
\text { - IA-9, Service } \\
\text { Identification and } \\
\text { Authentication }\end{array}$ & $\begin{array}{l}\text { - Cannot identify or } \\
\text { authenticate users, } \\
\text { devices, and } \\
\text { processes. }\end{array}$ & $\begin{array}{l}\text { - PR.AC-1: Identities and } \\
\text { credentials are issued, } \\
\text { managed, verified, revoked, } \\
\text { and audited for authorized } \\
\text { devices, users and } \\
\text { processes } \\
\text { - PR.AC-7: Users, devices, } \\
\text { and other assets are } \\
\text { authenticated (e.g., single- } \\
\text { factor, multi-factor) } \\
\text { commensurate with the risk } \\
\text { of the transaction (e.g., } \\
\text { individuals' security and } \\
\text { privacy risks and other } \\
\text { organizational risks) }\end{array}$ \\
\hline
\end{tabular}




\begin{tabular}{|c|c|c|c|}
\hline $\begin{array}{l}\text { Challenges for Individual } \\
\text { loT Devices, and } \\
\text { Risk Considerations } \\
\text { Causing the Challenges }\end{array}$ & $\begin{array}{c}\text { Affected Draft NIST SP } \\
\text { 800-53 Revision } 5 \\
\text { Controls }\end{array}$ & $\begin{array}{l}\text { Implications for the } \\
\text { Organization }\end{array}$ & $\begin{array}{l}\text { Affected Cybersecurity } \\
\text { Framework Subcategories }\end{array}$ \\
\hline $\begin{array}{l}\text { 15. The loT device may } \\
\text { only support the use of } \\
\text { one or more shared } \\
\text { identifiers. } \\
\text { Risk Considerations } 2 \\
\text { and } 3\end{array}$ & $\begin{array}{l}\text { - IA-2, Identification and } \\
\text { Authentication } \\
\text { (Organizational Users) } \\
\text { - IA-3, Device } \\
\text { Identification and } \\
\text { Authentication } \\
\text { - IA-4, Identifier } \\
\text { Management } \\
\text { - IA-8, Identification and } \\
\text { Authentication (Non- } \\
\text { Organizational Users) } \\
\text { - IA-9, Service } \\
\text { Identification and } \\
\text { Authentication }\end{array}$ & $\begin{array}{l}\text { - Cannot uniquely } \\
\text { identify users, } \\
\text { devices, and } \\
\text { processes. } \\
\text { Complicates } \\
\text { credential } \\
\text { management } \\
\text { because of shared } \\
\text { credentials. }\end{array}$ & $\begin{array}{l}\text { PR.AC-1: Identities and } \\
\text { credentials are issued, } \\
\text { managed, verified, revoked, } \\
\text { and audited for authorized } \\
\text { devices, users and } \\
\text { processes }\end{array}$ \\
\hline $\begin{array}{l}\text { 16. The loT device may } \\
\text { require the use of } \\
\text { identifiers but only in } \\
\text { certain cases (for } \\
\text { example, for remote } \\
\text { access but not local } \\
\text { access, or for } \\
\text { administration } \\
\text { purposes but not } \\
\text { regular usage). } \\
\text { Risk Considerations } 2 \\
\text { and } 3\end{array}$ & $\begin{array}{l}\text { - IA-2, Identification and } \\
\text { Authentication } \\
\text { (Organizational Users) } \\
\text { - IA-3, Device } \\
\text { Identification and } \\
\text { Authentication } \\
\text { - IA-4, Identifier } \\
\text { Management } \\
\text { - IA-8, Identification and } \\
\text { Authentication (Non- } \\
\text { Organizational Users) } \\
\text { - IA-9, Service } \\
\text { Identification and } \\
\text { Authentication }\end{array}$ & $\begin{array}{l}\text { Cannot identify or } \\
\text { authenticate some } \\
\text { users, devices, and } \\
\text { processes. }\end{array}$ & $\begin{array}{l}\text { - PR.AC-1: Identities and } \\
\text { credentials are issued, } \\
\text { managed, verified, revoked, } \\
\text { and audited for authorized } \\
\text { devices, users and } \\
\text { processes } \\
\text { - PR.AC-7: Users, devices, } \\
\text { and other assets are } \\
\text { authenticated (e.g., single- } \\
\text { factor, multi-factor) } \\
\text { commensurate with the risk } \\
\text { of the transaction (e.g., } \\
\text { individuals' security and } \\
\text { privacy risks and other } \\
\text { organizational risks) }\end{array}$ \\
\hline \multicolumn{4}{|c|}{$\begin{array}{l}\text { Expectation 9: The device can conceal password characters from display when a person enters a password for a } \\
\text { device, such as on a keyboard or touch screen. }\end{array}$} \\
\hline $\begin{array}{l}\text { 17. The loT device may } \\
\text { not support } \\
\text { concealment of } \\
\text { displayed password } \\
\text { characters. } \\
\text { Risk Considerations } 2 \\
\text { and } 3\end{array}$ & $\begin{array}{l}\text { - IA-6, Authenticator } \\
\text { Feedback }\end{array}$ & $\begin{array}{l}\text { - Increases the } \\
\text { likelihood of } \\
\text { credential theft. }\end{array}$ & $\begin{array}{l}\text { PR.AC-7: Users, devices, } \\
\text { and other assets are } \\
\text { authenticated (e.g., single- } \\
\text { factor, multi-factor) } \\
\text { commensurate with the risk } \\
\text { of the transaction (e.g., } \\
\text { individuals' security and } \\
\text { privacy risks and other } \\
\text { organizational risks) }\end{array}$ \\
\hline \multicolumn{4}{|c|}{ Expectation 10: The device can authenticate each user, device, and process attempting to logically access it. } \\
\hline $\begin{array}{l}\text { 18. The loT device may } \\
\text { not support use of } \\
\text { non-trivial credentials } \\
\text { (e.g., does not support } \\
\text { the use of identifiers, } \\
\text { does not allow default } \\
\text { passwords to be } \\
\text { changed). } \\
\text { Risk Considerations } 2 \\
\text { and } 3\end{array}$ & $\begin{array}{l}\text { - IA-5, Authenticator } \\
\text { Management }\end{array}$ & $\begin{array}{l}\text { - Cannot identify or } \\
\text { authenticate users, } \\
\text { devices, and } \\
\text { processes, which } \\
\text { increases the } \\
\text { chances of } \\
\text { unauthorized access } \\
\text { and tampering. }\end{array}$ & $\begin{array}{l}\text { PR.AC-7: Users, devices, } \\
\text { and other assets are } \\
\text { authenticated (e.g., single- } \\
\text { factor, multi-factor) } \\
\text { commensurate with the risk } \\
\text { of the transaction (e.g., } \\
\text { individuals' security and } \\
\text { privacy risks and other } \\
\text { organizational risks) }\end{array}$ \\
\hline
\end{tabular}




\begin{tabular}{|c|c|c|c|}
\hline $\begin{array}{l}\text { Challenges for Individual } \\
\text { loT Devices, and } \\
\text { Risk Considerations } \\
\text { Causing the Challenges }\end{array}$ & $\begin{array}{c}\text { Affected Draft NIST SP } \\
\text { 800-53 Revision } 5 \\
\text { Controls }\end{array}$ & $\begin{array}{l}\text { Implications for the } \\
\text { Organization }\end{array}$ & $\begin{array}{l}\text { Affected Cybersecurity } \\
\text { Framework Subcategories }\end{array}$ \\
\hline $\begin{array}{l}\text { 19. The loT device may } \\
\text { not support the use of } \\
\text { strong credentials, } \\
\text { such as cryptographic } \\
\text { tokens or multifactor } \\
\text { authentication, for the } \\
\text { situations that merit } \\
\text { them. } \\
\text { Risk Consideration } 3\end{array}$ & $\begin{array}{l}\text { - IA-5, Authenticator } \\
\text { Management }\end{array}$ & $\begin{array}{l}\text { - Increases the } \\
\text { chances of } \\
\text { unauthorized access } \\
\text { and tampering } \\
\text { through credential } \\
\text { misuse. }\end{array}$ & $\begin{array}{l}\text { PR.AC-7: Users, devices, } \\
\text { and other assets are } \\
\text { authenticated (e.g., single- } \\
\text { factor, multi-factor) } \\
\text { commensurate with the risk } \\
\text { of the transaction (e.g., } \\
\text { individuals' security and } \\
\text { privacy risks and other } \\
\text { organizational risks) }\end{array}$ \\
\hline \multicolumn{4}{|c|}{ Expectation 11: The device can use existing enterprise authenticators and authentication mechanisms. } \\
\hline $\begin{array}{l}\text { 20. The loT device may } \\
\text { not support the use of } \\
\text { an existing enterprise } \\
\text { user authentication } \\
\text { system. } \\
\text { Risk Consideration } 3\end{array}$ & $\begin{array}{l}\text { - IA-2, Identification and } \\
\text { Authentication } \\
\text { (Organizational Users) } \\
\text { - IA-5, Authenticator } \\
\text { Management } \\
\text { - IA-8, Identification and } \\
\text { Authentication (Non- } \\
\text { Organizational Users) }\end{array}$ & $\begin{array}{l}\text { Need one or more } \\
\text { additional accounts } \\
\text { and credentials for } \\
\text { each user. }\end{array}$ & $\begin{array}{l}\text { - PR.AC-1: Identities and } \\
\text { credentials are issued, } \\
\text { managed, verified, revoked, } \\
\text { and audited for authorized } \\
\text { devices, users and } \\
\text { processes } \\
\text { - PR.AC-7: Users, devices, } \\
\text { and other assets are } \\
\text { authenticated (e.g., single- } \\
\text { factor, multi-factor) } \\
\text { commensurate with the risk } \\
\text { of the transaction (e.g., } \\
\text { individuals' security and } \\
\text { privacy risks and other } \\
\text { organizational risks) }\end{array}$ \\
\hline \multicolumn{4}{|c|}{$\begin{array}{l}\text { Expectation 12: The device can restrict each user, device, and process to the minimum logical access privileges } \\
\text { necessary. }\end{array}$} \\
\hline $\begin{array}{l}\text { 21. The loT device may } \\
\text { not support use of } \\
\text { logical access } \\
\text { privileges within the } \\
\text { device that is sufficient } \\
\text { for a given situation. } \\
\text { Risk Consideration } 3\end{array}$ & $\begin{array}{l}\text { - AC-3, Access } \\
\text { Enforcement } \\
\text { - AC-5, Separation of } \\
\text { Duties } \\
\text { - AC-6, Least Privilege }\end{array}$ & $\begin{array}{l}\text { - Allows authorized } \\
\text { users, devices, and } \\
\text { processes to } \\
\text { intentionally or } \\
\text { inadvertently use } \\
\text { privileges they } \\
\text { should not have. } \\
\text { - Allows an attacker } \\
\text { who gains } \\
\text { unauthorized access } \\
\text { to an account to have } \\
\text { even greater access } \\
\text { than the account } \\
\text { should have. }\end{array}$ & $\begin{array}{l}\text { - PR.AC-4: Access } \\
\text { permissions and } \\
\text { authorizations are managed, } \\
\text { incorporating the principles } \\
\text { of least privilege and } \\
\text { separation of duties } \\
\text { - PR.DS-5: Protections } \\
\text { against data leaks are } \\
\text { implemented } \\
\text { - PR.MA-1: Maintenance and } \\
\text { repair of organizational } \\
\text { assets are performed and } \\
\text { logged, with approved and } \\
\text { controlled tools }\end{array}$ \\
\hline
\end{tabular}




\begin{tabular}{|c|c|c|c|}
\hline $\begin{array}{l}\text { Challenges for Individual } \\
\text { loT Devices, and } \\
\text { Risk Considerations } \\
\text { Causing the Challenges }\end{array}$ & $\begin{array}{c}\text { Affected Draft NIST SP } \\
\text { 800-53 Revision } 5 \\
\text { Controls }\end{array}$ & $\begin{array}{l}\text { Implications for the } \\
\text { Organization }\end{array}$ & $\begin{array}{l}\text { Affected Cybersecurity } \\
\text { Framework Subcategories }\end{array}$ \\
\hline $\begin{array}{l}\text { 22. The loT device may } \\
\text { not support use of } \\
\text { logical access } \\
\text { privileges to restrict } \\
\text { network } \\
\text { communications into } \\
\text { and out of the device } \\
\text { that is sufficient for a } \\
\text { given situation. } \\
\text { Risk Consideration } 3\end{array}$ & $\begin{array}{l}\text { - AC-3, Access } \\
\text { Enforcement } \\
\text { - AC-4, Information } \\
\text { Flow Enforcement } \\
\text { - AC-5, Separation of } \\
\text { Duties } \\
\text { - AC-6, Least Privilege } \\
\text { - AC-17, Remote } \\
\text { Access } \\
\text { - SC-7, Boundary } \\
\text { Protection }\end{array}$ & $\begin{array}{l}\text { - Allows authorized } \\
\text { users, devices, and } \\
\text { processes to } \\
\text { intentionally or } \\
\text { inadvertently conduct } \\
\text { network } \\
\text { communications they } \\
\text { should not be able to. } \\
\text { - Allows an attacker to } \\
\text { have greater network } \\
\text { access than } \\
\text { intended. }\end{array}$ & $\begin{array}{l}\text { - PR.AC-3: Remote access is } \\
\text { managed } \\
\text { - PR.AC-5: Network integrity } \\
\text { is protected (e.g., network } \\
\text { segregation, network } \\
\text { segmentation) } \\
\text { - PR.DS-5: Protections } \\
\text { against data leaks are } \\
\text { implemented } \\
\text { - PR.MA-2: Remote } \\
\text { maintenance of } \\
\text { organizational assets is } \\
\text { approved, logged, and } \\
\text { performed in a manner that } \\
\text { prevents unauthorized } \\
\text { access }\end{array}$ \\
\hline
\end{tabular}

Expectation 13: The device can thwart attempts to gain unauthorized access, and this feature can be configured or disabled to avoid undesired disruptions to availability. (Examples include locking or disabling an account when there are too many consecutive failed authentication attempts, delaying additional authentication attempts after failed attempts, and locking or terminating idle sessions.)

\begin{tabular}{|c|c|c|c|}
\hline $\begin{array}{l}\text { 23. The loT device's use } \\
\text { of these security } \\
\text { features may not be } \\
\text { sufficiently modifiable. } \\
\text { Risk Considerations } 1 \\
\text { and } 3\end{array}$ & $\begin{array}{l}\text { - AC-7, Unsuccessful } \\
\text { Logon Attempts } \\
\text { - AC-11, Device Lock } \\
\text { - AC-12, Session } \\
\text { Termination } \\
\text { - IA-11, Re- } \\
\text { Authentication }\end{array}$ & $\begin{array}{l}\text { - Cannot gain } \\
\text { immediate access to } \\
\text { loT devices when } \\
\text { needed to use or } \\
\text { manage them. }\end{array}$ & $\begin{array}{l}\text { - PR.AC-3: Remote access is } \\
\text { managed } \\
\text { - PR.AC-4: Access } \\
\text { permissions and } \\
\text { authorizations are managed, } \\
\text { incorporating the principles } \\
\text { of least privilege and } \\
\text { separation of duties } \\
\text { - PR.MA-1: Maintenance and } \\
\text { repair of organizational } \\
\text { assets are performed and } \\
\text { logged, with approved and } \\
\text { controlled tools } \\
\text { - PR.MA-2: Remote } \\
\text { maintenance of } \\
\text { organizational assets is } \\
\text { approved, logged, and } \\
\text { performed in a manner that } \\
\text { prevents unauthorized } \\
\text { access }\end{array}$ \\
\hline
\end{tabular}




\begin{tabular}{|c|c|c|c|}
\hline $\begin{array}{c}\text { Challenges for Individual } \\
\text { loT Devices, and } \\
\text { Risk Considerations } \\
\text { Causing the Challenges }\end{array}$ & $\begin{array}{c}\text { Affected Draft NIST SP } \\
\text { 800-53 Revision } 5 \\
\text { Controls }\end{array}$ & $\begin{array}{l}\text { Implications for the } \\
\text { Organization }\end{array}$ & $\begin{array}{l}\text { Affected Cybersecurity } \\
\text { Framework Subcategories }\end{array}$ \\
\hline \multicolumn{4}{|c|}{$\begin{array}{l}\text { Expectation 14: The device has adequate built-in physical security controls to protect it from tampering (e.g., } \\
\text { tamper-resistant packaging). }\end{array}$} \\
\hline $\begin{array}{l}\text { 24. The loT device may } \\
\text { be deployed in an } \\
\text { area where people } \\
\text { who are not } \\
\text { authorized to access } \\
\text { the device may do so } \\
\text { or where authorized } \\
\text { people can access the } \\
\text { device in unauthorized } \\
\text { ways. } \\
\text { Risk Considerations } 1 \\
\text { and } 2\end{array}$ & $\begin{array}{l}\text { - MP-2, Media Access } \\
\text { - MP-7, Media Use } \\
\text { - PE-3, Physical Access } \\
\text { Control }\end{array}$ & $\begin{array}{l}\text { - Allows an attacker to } \\
\text { have direct physical } \\
\text { access to devices } \\
\text { and tamper with } \\
\text { them, including } \\
\text { adding or removing } \\
\text { storage media, } \\
\text { connecting } \\
\text { peripherals, etc. }\end{array}$ & $\begin{array}{l}\text { - PR.AC-2: Physical access to } \\
\text { assets is managed and } \\
\text { protected } \\
\text { - PR.PT-2: Removable media } \\
\text { is protected and its use } \\
\text { restricted according to policy } \\
\text { - PR.MA-1: Maintenance and } \\
\text { repair of organizational } \\
\text { assets are performed and } \\
\text { logged, with approved and } \\
\text { controlled tools }\end{array}$ \\
\hline \multicolumn{4}{|l|}{ Incident Detection } \\
\hline \multicolumn{4}{|c|}{ Expectation 15: The device can log its operational and security events. } \\
\hline $\begin{array}{l}\text { 25. The loT device may } \\
\text { not be able to log its } \\
\text { operational and } \\
\text { security events at all } \\
\text { or in sufficient detail. } \\
\text { Risk Consideration } 3\end{array}$ & $\begin{array}{l}\text { - } \text { AU-2, Audit Events } \\
\text { - } \text { AU-3, Content of Audit } \\
\text { Records } \\
\text { - } \text { AU-12, Audit } \\
\text { Generation } \\
\text { - Sl-4, System } \\
\text { Monitoring }\end{array}$ & $\begin{array}{l}\text { - Increases the } \\
\text { likelihood of } \\
\text { malicious activity } \\
\text { going undetected. } \\
\text { - Cannot confirm and } \\
\text { reconstruct incidents } \\
\text { from log entries. }\end{array}$ & $\begin{array}{l}\text { DE.CM-7: Monitoring for } \\
\text { unauthorized personnel, } \\
\text { connections, devices, and } \\
\text { software is performed } \\
\text { - PR.PT-1: Audit/log records } \\
\text { are determined, } \\
\text { documented, implemented, } \\
\text { and reviewed in accordance } \\
\text { with policy } \\
\text { - RS.AN-1: Notifications from } \\
\text { detection systems are } \\
\text { investigated }\end{array}$ \\
\hline $\begin{array}{l}\text { 26. The loT device may } \\
\text { continue operating } \\
\text { even when a logging } \\
\text { failure occurs. } \\
\text { Risk Consideration } 3\end{array}$ & $\begin{array}{l}\text { - AU-5, Response to } \\
\text { Audit Processing } \\
\text { Failures }\end{array}$ & $\begin{array}{l}\text { Increased likelihood } \\
\text { of malicious activity } \\
\text { going undetected. }\end{array}$ & $\begin{array}{l}\text { DE.CM-7: Monitoring for } \\
\text { unauthorized personnel, } \\
\text { connections, devices, and } \\
\text { software is performed } \\
\text { - PR.PT-1: Audit/log records } \\
\text { are determined, } \\
\text { documented, implemented, } \\
\text { and reviewed in accordance } \\
\text { with policy }\end{array}$ \\
\hline $\begin{array}{l}\text { 27. The loT device may } \\
\text { not be able to } \\
\text { participate in an } \\
\text { enterprise log } \\
\text { management system. } \\
\text { Risk Consideration } 2\end{array}$ & $\begin{array}{l}\text { - AU-6, Audit Review, } \\
\text { Analysis, and } \\
\text { Reporting } \\
\text { - SI-4, System } \\
\text { Monitoring }\end{array}$ & $\begin{array}{l}\text { - May have to use } \\
\text { numerous log } \\
\text { management } \\
\text { systems instead of } \\
\text { one. } \\
\text { - May have to perform } \\
\text { log management } \\
\text { tasks manually. } \\
\text { - Increases the } \\
\text { likelihood of } \\
\text { malicious activity } \\
\text { going undetected. }\end{array}$ & $\begin{array}{l}\text { DE.AE-3: Event data are } \\
\text { collected and correlated } \\
\text { from multiple sources and } \\
\text { sensors } \\
\text { - DE.CM-7: Monitoring for } \\
\text { unauthorized personnel, } \\
\text { connections, devices, and } \\
\text { software is performed } \\
\text { - PR.PT-1: Audit/log records } \\
\text { are determined, } \\
\text { documented, implemented, } \\
\text { and reviewed in accordance } \\
\text { with policy }\end{array}$ \\
\hline
\end{tabular}




\begin{tabular}{|c|c|c|c|}
\hline $\begin{array}{l}\text { Challenges for Individual } \\
\text { loT Devices, and } \\
\text { Risk Considerations } \\
\text { Causing the Challenges }\end{array}$ & $\begin{array}{c}\text { Affected Draft NIST SP } \\
\text { 800-53 Revision } 5 \\
\text { Controls }\end{array}$ & $\begin{array}{l}\text { Implications for the } \\
\text { Organization }\end{array}$ & $\begin{array}{l}\text { Affected Cybersecurity } \\
\text { Framework Subcategories }\end{array}$ \\
\hline \multicolumn{4}{|c|}{$\begin{array}{l}\text { Expectation 17: The device can facilitate the detection of potential incidents by internal or external controls, such } \\
\text { as intrusion prevention systems, anti-malware utilities, and file integrity checking mechanisms. }\end{array}$} \\
\hline $\begin{array}{l}\text { 28. The loT device may } \\
\text { not be able to execute } \\
\text { internal detection } \\
\text { controls or interact } \\
\text { with external detection } \\
\text { controls without } \\
\text { adversely affecting } \\
\text { device operation. } \\
\text { Risk Considerations } 1 \\
\text { and } 3\end{array}$ & $\begin{array}{l}\text { - SI-3, Malicious Code } \\
\text { Protection } \\
\text { - SI-7, Software, } \\
\text { Firmware, and } \\
\text { Information Integrity }\end{array}$ & $\begin{array}{l}\text { - Increases the } \\
\text { likelihood of } \\
\text { malicious code } \\
\text { infections and other } \\
\text { unauthorized } \\
\text { activities occurring } \\
\text { and going } \\
\text { undetected. }\end{array}$ & $\begin{array}{l}\text { - DE.CM-1: The network is } \\
\text { monitored to detect potential } \\
\text { cybersecurity events } \\
\text { - DE.CM-4: Malicious code is } \\
\text { detected } \\
\text { - PR.DS-6: Integrity checking } \\
\text { mechanisms are used to } \\
\text { verify software, firmware, } \\
\text { and information integrity }\end{array}$ \\
\hline $\begin{array}{l}\text { 29. The loT device may } \\
\text { not provide controls } \\
\text { with the visibility } \\
\text { needed to detect } \\
\text { incidents efficiently } \\
\text { and effectively. } \\
\text { Risk Considerations } 2 \\
\text { and } 3\end{array}$ & $\begin{array}{l}\text { - IR-4, Incident } \\
\text { Handling } \\
\text { - SI-4, System } \\
\text { Monitoring }\end{array}$ & $\begin{array}{l}\text { - Increases the } \\
\text { likelihood of } \\
\text { malicious code and } \\
\text { other unauthorized } \\
\text { activities going } \\
\text { undetected. }\end{array}$ & $\begin{array}{l}\text { - DE.CM-1: The network is } \\
\text { monitored to detect potential } \\
\text { cybersecurity events } \\
\text { - DE.CM-4: Malicious code is } \\
\text { detected } \\
\text { - PR.DS-6: Integrity checking } \\
\text { mechanisms are used to } \\
\text { verify software, firmware, } \\
\text { and information integrity }\end{array}$ \\
\hline \multicolumn{4}{|c|}{ Expectation 18: The device can support event and incident analysis activities. } \\
\hline $\begin{array}{l}\text { 30. The loT device may } \\
\text { not provide analysts } \\
\text { with sufficient access } \\
\text { to the device's } \\
\text { resources in order to } \\
\text { do the necessary } \\
\text { analysis. } \\
\text { Risk Considerations } 2 \\
\text { and } 3\end{array}$ & $\begin{array}{l}\text { - SI-4, System } \\
\text { Monitoring }\end{array}$ & $\begin{array}{l}\text { - Cannot use forensic } \\
\text { tools for information } \\
\text { gathering and } \\
\text { analysis. }\end{array}$ & $\begin{array}{l}\text { - RS.AN-1: Notifications from } \\
\text { detection systems are } \\
\text { investigated } \\
\text { - RS.AN-3: Forensics are } \\
\text { performed }\end{array}$ \\
\hline
\end{tabular}

\subsection{Potential Challenges with Achieving Goal 2, Protect Data Security}

Table 2 follows the same conventions as Table 1, but for protecting data security. It is assumed that if data security needs to be protected, device security needs protection as well, so the challenges in both tables would need to be considered.

Note that the Incident Detection section of Table 1 is also applicable for protecting data security. Table 1 assumes only device security incidents need to be protected; the same potential challenges, affected controls, implications, and Cybersecurity Framework subcategories also apply to detecting data security incidents. The Incident Detection rows are omitted from Table 2 for brevity. 
Table 2: Potential Challenges with Achieving Goal 2, Protect Data Security

\begin{tabular}{|c|c|c|c|}
\hline $\begin{array}{l}\text { Challenges for Individual loT } \\
\text { Devices }\end{array}$ & $\begin{array}{c}\text { Affected Draft NIST } \\
\text { SP 800-53 Revision } \\
5 \text { Controls }\end{array}$ & $\begin{array}{l}\text { Implications for the } \\
\text { Organization }\end{array}$ & $\begin{array}{c}\text { Affected Cybersecurity } \\
\text { Framework } \\
\text { Subcategories }\end{array}$ \\
\hline \multicolumn{4}{|l|}{ Data Protection } \\
\hline \multicolumn{4}{|c|}{ Expectation 19: The device can prevent unauthorized access to all sensitive data on its storage devices. } \\
\hline $\begin{array}{l}\text { 31. The loT device may not } \\
\text { provide sufficiently strong } \\
\text { encryption capabilities for its } \\
\text { stored data. } \\
\text { Risk Consideration } 3\end{array}$ & $\begin{array}{l}\text { - MP-4, Media } \\
\text { Storage } \\
\text { - SC-28, Protection } \\
\text { of Information at } \\
\text { Rest }\end{array}$ & $\begin{array}{l}\text { - Increases the likelihood } \\
\text { of unauthorized access } \\
\text { to or tampering with } \\
\text { sensitive data. }\end{array}$ & $\begin{array}{l}\text { - PR.DS-1: Data-at-rest } \\
\text { is protected } \\
\text { - PR.PT-2: Removable } \\
\text { media is protected } \\
\text { and its use restricted } \\
\text { according to policy }\end{array}$ \\
\hline $\begin{array}{l}\text { 32. The loT device may not } \\
\text { provide a mechanism for } \\
\text { sanitizing sensitive data } \\
\text { before disposing of or } \\
\text { repurposing the device. } \\
\text { Risk Consideration } 3\end{array}$ & $\begin{array}{l}\text { - MP-6, Media } \\
\text { Sanitization }\end{array}$ & $\begin{array}{l}\text { - Increases the likelihood } \\
\text { of unauthorized access } \\
\text { to sensitive data. }\end{array}$ & $\begin{array}{l}\text { PR.IP-6: Data is } \\
\text { destroyed according } \\
\text { to policy }\end{array}$ \\
\hline \multicolumn{4}{|c|}{ Expectation 20: The device has a mechanism to support data availability through secure backups. } \\
\hline $\begin{array}{l}\text { 33. The loT device may not } \\
\text { provide a secure backup } \\
\text { and restore mechanism for } \\
\text { its data. } \\
\text { Risk Consideration } 3\end{array}$ & $\begin{array}{l}\text { - CP-9, System } \\
\text { Backup }\end{array}$ & $\begin{array}{l}\text { - Increases the likelihood } \\
\text { of loss of data. }\end{array}$ & $\begin{array}{l}\text { - PR.IP-4: Backups of } \\
\text { information are } \\
\text { conducted, } \\
\text { maintained, and } \\
\text { tested }\end{array}$ \\
\hline \multicolumn{4}{|c|}{$\begin{array}{l}\text { Expectation 21: The device can prevent unauthorized access to all sensitive data transmitted from it over } \\
\text { networks. }\end{array}$} \\
\hline $\begin{array}{l}\text { 34. The loT device may not } \\
\text { provide sufficiently strong } \\
\text { encryption capabilities for } \\
\text { protecting sensitive data } \\
\text { sent in its network } \\
\text { communications. } \\
\text { Risk Consideration } 3\end{array}$ & $\begin{array}{l}\text { - AC-18, Wireless } \\
\text { Access } \\
\text { - SC-8, Transmission } \\
\text { Confidentiality and } \\
\text { Integrity }\end{array}$ & $\begin{array}{l}\text { - Increases the likelihood } \\
\text { of eavesdropping on } \\
\text { communications. }\end{array}$ & $\begin{array}{l}\text { - PR.DS-2: Data-in- } \\
\text { transit is protected }\end{array}$ \\
\hline $\begin{array}{l}\text { 35. The loT device may not } \\
\text { verify the identity of another } \\
\text { computing device before } \\
\text { sending sensitive data in its } \\
\text { network communications. } \\
\text { Risk Consideration } 3\end{array}$ & $\begin{array}{l}\text { - SC-8, Transmission } \\
\text { Confidentiality and } \\
\text { Integrity } \\
\text { - SC-23, Session } \\
\text { Authenticity }\end{array}$ & $\begin{array}{l}\text { - Increases the likelihood } \\
\text { of eavesdropping, } \\
\text { interception, } \\
\text { manipulation, } \\
\text { impersonation, and } \\
\text { other forms of attack } \\
\text { on communications. }\end{array}$ & $\begin{array}{l}\text { PR.DS-2: Data-in- } \\
\text { transit is protected }\end{array}$ \\
\hline
\end{tabular}

\subsection{Potential Challenges with Achieving Goal 3, Protect Individuals' Privacy}

Table 3 lists potential challenges with achieving goal 3, protecting individuals' privacy by mitigating privacy risk arising from authorized PII processing. It follows the same conventions as the previous tables, but it omits mappings to Cybersecurity Framework Subcategories since the Cybersecurity Framework does not address privacy risks from authorized PII processing. It is assumed that if individuals' privacy needs to be protected, device and data security need to be protected as well, so the challenges in all three tables would need to be considered. However, organizations may use information from Table 2 to address privacy risks arising from the loss of confidentiality, integrity, or availability of PII. 
Table 3: Potential Challenges with Achieving Goal 3, Protect Individuals' Privacy

\begin{tabular}{|c|c|c|}
\hline Challenges for Individual loT Devices & $\begin{array}{c}\text { Affected Draft NIST } \\
\text { SP 800-53 Revision } \\
5 \text { Controls }\end{array}$ & Implications for the Organization \\
\hline \multicolumn{3}{|l|}{ Disassociated Data Management } \\
\hline \multicolumn{3}{|c|}{ Expectation 22: The device operates in a traditional federated identity environment. } \\
\hline $\begin{array}{l}\text { 36. The loT device may contribute data that } \\
\text { is used for identification and } \\
\text { authentication, but is outside of } \\
\text { traditional federated environments. } \\
\text { Risk Consideration } 3\end{array}$ & $\begin{array}{l}\text { IA-8 (6), Identification } \\
\text { and Authentication } \\
\text { (non-organizational } \\
\text { users) | } \\
\text { Disassociability }\end{array}$ & $\begin{array}{l}\text { - Techniques such as the use of } \\
\text { identifier mapping tables and privacy- } \\
\text { enhancing cryptographic techniques to } \\
\text { blind credential service providers and } \\
\text { relying parties from each other or to } \\
\text { make identity attributes less visible to } \\
\text { transmitting parties may not work } \\
\text { outside a traditional federated } \\
\text { environment. }\end{array}$ \\
\hline \multicolumn{3}{|l|}{ Informed Decision Making } \\
\hline \multicolumn{3}{|c|}{ Expectation 23: Traditional interfaces exist for individual engagement with the device. } \\
\hline $\begin{array}{l}\text { 37. The loT device may lack interfaces that } \\
\text { enable individuals to interact with it. } \\
\text { Risk Consideration } 2\end{array}$ & IP-2, Consent & $\begin{array}{l}\text { - Individuals may not be able to provide } \\
\text { consent for the processing of their PII } \\
\text { or condition further processing of } \\
\text { specific attributes. }\end{array}$ \\
\hline $\begin{array}{l}\text { 38. Decentralized data processing functions } \\
\text { and heterogenous ownership of IoT } \\
\text { devices challenge traditional } \\
\text { accountability processes. } \\
\text { Risk Consideration } 3\end{array}$ & IP-3, Redress & $\begin{array}{l}\text { - Individuals may not be able to locate } \\
\text { the source of inaccurate or otherwise } \\
\text { problematic PII in order to correct it or } \\
\text { fix the problem. }\end{array}$ \\
\hline $\begin{array}{l}\text { 39. The loT device may lack interfaces that } \\
\text { enable individuals to read privacy } \\
\text { notices. } \\
\text { Risk Consideration } 2\end{array}$ & IP-4, Privacy Notice & $\begin{array}{l}\text { - Individuals may not be able to read or } \\
\text { access privacy notices. }\end{array}$ \\
\hline $\begin{array}{l}\text { 40. The loT device may lack interfaces to } \\
\text { enable access to PII, or PII may be } \\
\text { stored in unknown locations. } \\
\text { Risk Consideration } 2\end{array}$ & $\begin{array}{l}\text { IP-6, Individual } \\
\text { Access }\end{array}$ & $\begin{array}{l}\text { - Individuals may have difficulty } \\
\text { accessing their information, which } \\
\text { curtails their ability to manage their } \\
\text { information and understand what is } \\
\text { happening with their data, and } \\
\text { increases compliance risks. }\end{array}$ \\
\hline \multicolumn{3}{|l|}{ PII Processing Permissions Management } \\
\hline \multicolumn{3}{|c|}{ Expectation 24: There is sufficient centralized control to apply policy or regulatory requirements to PII. } \\
\hline $\begin{array}{l}\text { 41. The loT device may collect PII } \\
\text { indiscriminately or analyze, share, or act } \\
\text { upon the PII based on automated } \\
\text { processes. } \\
\text { Risk Consideration } 2\end{array}$ & $\begin{array}{l}\text { PA-2, Authority to } \\
\text { Collect }\end{array}$ & $\begin{array}{l}\text { - PII may be processed in ways that are } \\
\text { out of compliance with regulatory } \\
\text { requirements or an organization's } \\
\text { policies. }\end{array}$ \\
\hline $\begin{array}{l}\text { 42. IoT devices may be complex and } \\
\text { dynamic, with sensing functionality that } \\
\text { can collect PII being frequently added } \\
\text { and removed. } \\
\text { Risk Consideration } 1\end{array}$ & $\begin{array}{l}\text { PA-3, Purpose } \\
\text { Specification }\end{array}$ & $\begin{array}{l}\text { - PII may be hard to track such that } \\
\text { individuals, as well as device } \\
\text { owners/operators, may not have } \\
\text { reliable assumptions about how PII is } \\
\text { being processed, causing informed } \\
\text { decision making to be more difficult. }\end{array}$ \\
\hline
\end{tabular}




\begin{tabular}{|c|c|c|}
\hline Challenges for Individual loT Devices & $\begin{array}{l}\text { Affected Draft NIST } \\
\text { SP 800-53 Revision } \\
5 \text { Controls }\end{array}$ & Implications for the Organization \\
\hline $\begin{array}{l}\text { 43. The loT device may be accessed } \\
\text { remotely, allowing the sharing of PII } \\
\text { outside the control of the administrator. } \\
\text { Risk Consideration } 2\end{array}$ & $\begin{array}{l}\text { PA-4, Information } \\
\text { Sharing with External } \\
\text { Parties }\end{array}$ & $\begin{array}{l}\text { PIl may be shared in ways that are out } \\
\text { of compliance with regulatory } \\
\text { requirements or an organization's } \\
\text { policies. }\end{array}$ \\
\hline \multicolumn{3}{|l|}{ Information Flow Management } \\
\hline \multicolumn{3}{|c|}{ Expectation 25: There is sufficient centralized control to manage PII. } \\
\hline $\begin{array}{l}\text { 44. IOT devices may be complex and } \\
\text { dynamic, with sensing functionality that } \\
\text { can collect PII being frequently added } \\
\text { and removed. } \\
\text { Risk Consideration } 1\end{array}$ & $\begin{array}{l}\text { PM-29, Inventory of } \\
\text { Personally Identifiable } \\
\text { Information }\end{array}$ & $\begin{array}{l}\text { - PII may be difficult to identify and track } \\
\text { using traditional inventory methods. }\end{array}$ \\
\hline $\begin{array}{l}\text { 45. IoT devices may not support } \\
\text { standardized mechanisms for centralized } \\
\text { data management, and the sheer } \\
\text { number of loT devices to manage may } \\
\text { be overwhelming. } \\
\text { Risk Consideration } 2\end{array}$ & $\begin{array}{l}\text { SC-7 (24), Boundary } \\
\text { Protection | } \\
\text { Personally Identifiable } \\
\text { Information }\end{array}$ & $\begin{array}{l}\text { - Application of PII processing rules } \\
\text { intended to protect individuals' privacy } \\
\text { may be disrupted. }\end{array}$ \\
\hline $\begin{array}{l}\text { 46. The loT device may not have the } \\
\text { capability to support configurations such } \\
\text { as remote activation prevention, limited } \\
\text { data reporting, notice of collection, and } \\
\text { data minimization. } \\
\text { Risk Consideration } 3\end{array}$ & $\begin{array}{l}\text { SC- } 42, \text { Sensor } \\
\text { Capability and Data }\end{array}$ & $\begin{array}{l}\text { - Lack of direct privacy risk mitigation } \\
\text { capabilities may require compensating } \\
\text { controls and may impact an } \\
\text { organization's ability to optimize the } \\
\text { amount of privacy risk that can be } \\
\text { reduced. }\end{array}$ \\
\hline $\begin{array}{l}\text { 47. The IoT device may indiscriminately } \\
\text { collect PlI. Heterogenous ownership of } \\
\text { devices challenges traditional data } \\
\text { management techniques. } \\
\text { Risk Consideration } 2\end{array}$ & $\begin{array}{l}\text { SI-12 (1), Information } \\
\text { Management and } \\
\text { Retention I Limit } \\
\text { Personally Identifiable } \\
\text { Information Elements }\end{array}$ & $\begin{array}{l}\text { - It is more likely that operationally } \\
\text { unnecessary PII will be retained. }\end{array}$ \\
\hline $\begin{array}{l}\text { 48. Decentralized data processing functions } \\
\text { and heterogenous ownership of loT } \\
\text { devices challenge traditional data } \\
\text { management processes with respect to } \\
\text { checking for accuracy of data. } \\
\text { Risk Consideration } 2\end{array}$ & $\begin{array}{l}\text { SI-19, Data Quality } \\
\text { Operations }\end{array}$ & $\begin{array}{l}\text { - It is more likely that inaccurate PII will } \\
\text { persist, with the potential to create } \\
\text { problems for individuals. }\end{array}$ \\
\hline $\begin{array}{l}\text { 49. Decentralized data processing functions } \\
\text { and heterogenous ownership of loT } \\
\text { devices challenge traditional de- } \\
\text { identification processes. } \\
\text { Risk Considerations } 2 \text { and } 3\end{array}$ & $\begin{array}{l}\mathrm{SI}-20, \mathrm{De}- \\
\text { Identification }\end{array}$ & $\begin{array}{l}\text { - Aggregation of disparate data sets } \\
\text { may lead to re-identification of PII. }\end{array}$ \\
\hline
\end{tabular}




\section{Recommendations for Addressing Cybersecurity and Privacy Risk Mitigation Challenges for loT Devices}

This section provides recommendations for addressing the cybersecurity and privacy risk mitigation challenges for IoT devices. Figure 6 summarizes the recommendations, which are listed below and, if indicated, described in more detail elsewhere in the publication:

1. Understand the IoT device risk considerations (Section 3) and the challenges they may cause to mitigating cybersecurity and privacy risks for IoT devices in the appropriate risk mitigation areas (Section 4).

2. Adjust organizational policies and processes to address the cybersecurity and privacy risk mitigation challenges throughout the IoT device

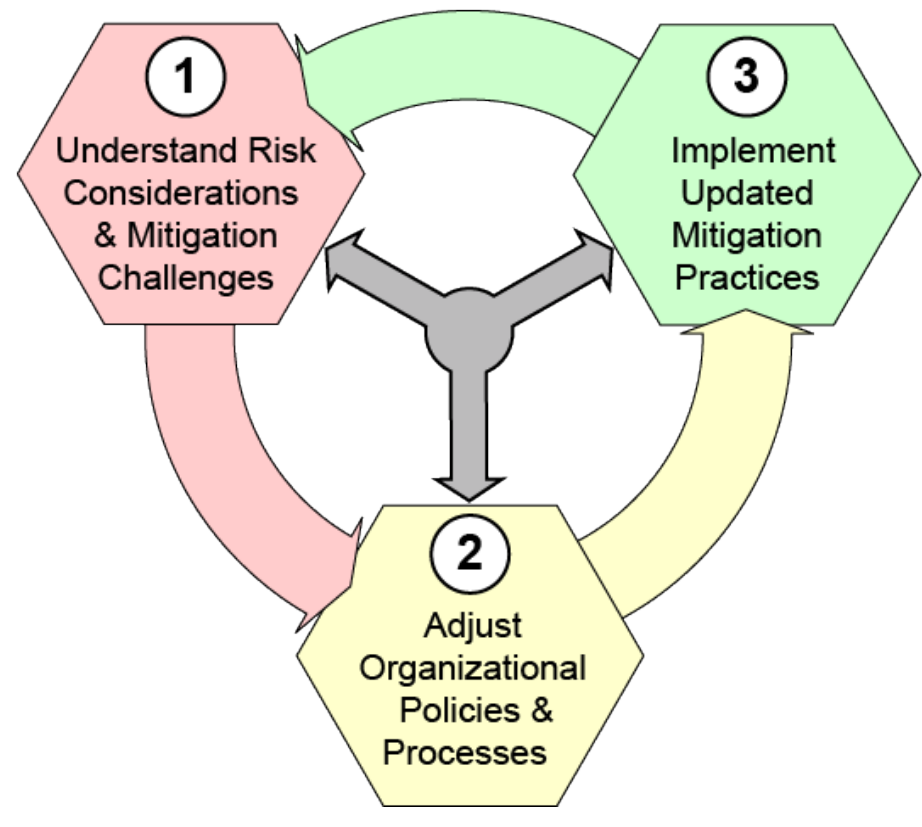

Figure 6: Recommendation Summary lifecycle. Section 5.1 provides more information on this. Section 4 of this publication cites many examples of possible challenges, but each organization will need to customize these to take into account mission requirements and other organization-specific characteristics.

3. Implement updated mitigation practices for the organization's IoT devices as you would any other changes to practices (Section 5.2).

\subsection{Adjusting Organizational Policies and Processes}

Organizations should ensure they are addressing the considerations throughout the IoT device lifecycle in their cybersecurity and privacy policies and processes. Organizations should ensure they clearly state how they scope IoT in order to avoid confusion and ambiguity. This is particularly important for organizations that may be subject to laws and regulations with differing definitions of IoT.

Similarly, organizations should ensure their cybersecurity, supply chain, and privacy risk management programs take IoT into account appropriately. This includes the following:

- Determining which devices have IoT device capabilities. Have mechanisms in place to determine whether a device that might be procured or has already been procured is an IoT device, if that is not apparent.

- Identifying IoT device types. Know which types of IoT devices are in use, which capabilities each type supports, and what purposes each type supports. 
- Assessing IoT device risk. It is important to take into consideration the particular IoT environment the IoT devices reside within, and not just assess risks for IoT devices in isolation. For example, attaching an actuator to one physical system may affect risks much differently than attaching the same actuator to another physical system.

- Determining how to respond to that risk by accepting, avoiding, mitigating, sharing, or transferring it. As previously discussed, some risk mitigation strategies for conventional IT may not work well for IoT. Section 4 of this publication discusses risk mitigation challenges for IoT devices in considerable detail.

Managing cybersecurity and privacy risks for some IoT devices may affect other types of risks and introduce new risks to safety, reliability, resiliency, performance, and other areas.

Organizations should be sure to consider the tradeoffs among these risks when making decisions about cybersecurity and privacy risk mitigation. For example, suppose a particular IoT device is critical for safety. Requiring personnel in a physically secured area to enter a password in order to gain local access to the IoT device could delay intervention during a malfunction. Additional requirements involving password length, password complexity, and automatic account lockouts after consecutive failed authentication attempts could cause far longer delays, increasing the likelihood and magnitude of harm. Organizations should leverage their existing programs for managing other forms of risk when determining how IoT device cybersecurity and privacy risks should be managed.

Based on the potential mitigation challenges and the implications of those challenges, the implementations of the following Cybersecurity Framework Subcategories [6] are most likely to need adjustments so the organizational policies and processes adequately address cybersecurity risk throughout the IoT device lifecycle:

- ID.AM (Identify_Asset Management)

ID.AM-1: Physical devices and systems within the organization are inventoried

○ ID.AM-2: Software platforms and applications within the organization are inventoried

- ID.BE (Identify_Business Environment)

- ID.BE-4: Dependencies and critical functions for delivery of critical services are established

- ID.BE-5: Resilience requirements to support delivery of critical services are established for all operating states (e.g. under duress/attack, during recovery, normal operations)

- ID.GV (Identify-Governance)

- ID.GV-1: Organizational cybersecurity policy is established and communicated

ID.GV-2: Cybersecurity roles and responsibilities are coordinated and aligned with internal roles and external partners

- ID.GV-3: Legal and regulatory requirements regarding cybersecurity, including privacy and civil liberties obligations, are understood and managed

ID.GV-4: Governance and risk management processes address cybersecurity risks 
- ID.RA (Identify—Risk Assessment)

- ID.RA-1: Asset vulnerabilities are identified and documented

O ID.RA-3: Threats, both internal and external, are identified and documented

- ID.RA-4: Potential business impacts and likelihoods are identified

○ ID.RA-6: Risk responses are identified and prioritized

- ID.RM (Identify_Risk Management Strategy)

- ID.RM-2: Organizational risk tolerance is determined and clearly expressed

- ID.RM-3: The organization's determination of risk tolerance is informed by its role in critical infrastructure and sector specific risk analysis

- ID.SC (Identify_-Supply Chain Risk Management)

- ID.SC-2: Suppliers and third party partners of information systems, components, and services are identified, prioritized, and assessed using a cyber supply chain risk assessment process

○ ID.SC-3: Contracts with suppliers and third-party partners are used to implement appropriate measures designed to meet the objectives of an organization's cybersecurity program and Cyber Supply Chain Risk Management Plan

- PR.IP (Protect - Information Protection Processes and Procedures)

○ PR.IP-3: Configuration change control processes are in place

○ PR.IP-9: Response plans (Incident Response and Business Continuity) and recovery plans (Incident Recovery and Disaster Recovery) are in place and managed

○ PR.IP-12: A vulnerability management plan is developed and implemented

Similarly, the implementations of the tasks listed below from NIST SP 800-37 Revision 2 [4] are most likely to need adjusted so the organizational policies and processes adequately address cybersecurity and privacy risk throughout the IoT device lifecycle. Note that although the Cybersecurity Framework can be used to manage the aspect of privacy relating to PII cybersecurity, NIST SP 800-37 Revision 2 can be used to manage the full scope of privacy because it integrates authorized PII processing into the NIST Risk Management Framework (RMF).

- Prepare, Organization Level, Task P-1: Risk Management Roles

- Prepare, Organization Level, Task P-2: Risk Management Strategy

- Prepare, Organization Level, Task P-3: Risk Assessment-Organization

- Prepare, System Level, Task P-8: Mission or Business Focus

- Prepare, System Level, Task P-13: Information Life Cycle

- Prepare, System Level, Task P-14: Risk Assessment-System

- Prepare, System Level, Task P-15: Requirements Definition 


\subsection{Implementing Updated Risk Mitigation Practices}

An organization's cybersecurity and privacy risk mitigation practices may need significant changes because of the sheer number of IoT devices and the large number of IoT device types. For conventional IT devices, most organizations have dozens of types - desktops, laptops, servers, smartphones, routers, switches, firewalls, printers, etc. Conventional IT devices within a single type tend to have similar capabilities. For example, most laptops have similar data storage and processing capabilities; human user interface and network interface capabilities; and supporting capabilities, such as centralized management. This enables organizations to determine how to manage risk for each of the dozens of conventional IT device types, with some customizations for particular devices and device models, and organizations are generally accustomed to this level of effort.

In contrast, most organizations may have many more types of IoT devices than conventional IT devices because of the single-purpose nature of most IoT devices. An organization may need to determine how to manage risk for hundreds or thousands of IoT device types. Capabilities vary widely from one IoT device type to another, with one type lacking data storage and centralized management capabilities, and another type having numerous sensors and actuators, using local and remote data storage and processing capabilities, and being connected to several internal and external networks at once. The variability in capabilities causes similar variability in the cybersecurity and privacy risks involving each IoT device type, as well as the options for mitigating those risks.

In addition, an organization may need to determine how to manage risk not just by device type, but also by device usage. The way a device is to be used may indicate that one security objective, such as integrity, is more important than another, such as confidentiality, and that in turn may necessitate different mechanisms to risk mitigation. Similarly, a device might be used in such a way that some of its capabilities are not needed and can be disabled, which could reduce the device's risk. 


\section{Appendix A-[Withdrawn]}

Appendix A previously held examples of possible cybersecurity and privacy capabilities that organizations may want their IoT devices to have. That content has been removed from this publication and will be refined and released in a separate publication which will be posted to our program website (https://www.nist.gov/programs-projects/nist-cybersecurity-iot-program). 


\section{Appendix B-Acronyms and Abbreviations}

Selected acronyms and abbreviations used in this paper are defined below.

$\begin{array}{ll}\text { API } & \text { Application Programming Interface } \\ \text { DDoS } & \text { Distributed Denial of Service } \\ \text { FISMA } & \text { Federal Information Security Modernization Act } \\ \text { FOIA } & \text { Freedom of Information Act } \\ \text { IETF } & \text { Internet Engineering Task Force } \\ \text { IoT } & \text { Internet of Things } \\ \text { IP } & \text { Internet Protocol } \\ \text { IR } & \text { Internal Report } \\ \text { IT } & \text { Information Technology } \\ \text { ITL } & \text { Information Technology Laboratory } \\ \text { LTE } & \text { Long-Term Evolution } \\ \text { NICE } & \text { National Initiative for Cybersecurity Education } \\ \text { NIST } & \text { National Institute of Standards and Technology } \\ \text { OMB } & \text { Office of Management and Budget } \\ \text { OT } & \text { Operational Technology } \\ \text { PII } & \text { Personally Identifiable Information } \\ \text { RFC } & \text { Request for Comments } \\ \text { RMF } & \text { Risk Management Framework } \\ \text { SLA } & \text { Service Level Agreement } \\ \text { SP } & \text { Special Publication }\end{array}$


Appendix C-Glossary

Actuating Capability

Application Interface

Capability

Capability

Data Actions

Disassociability

Human User Interface

Capability

Interface Capabilities

Network Interface

Capability

Personally Identifiable

Information (PII)

PII Processing

Post-Market Capability

Pre-Market Capability

Problematic Data Action
The ability to change something in the physical world.

The ability for other computing devices to communicate with an IoT device through an IoT device application.

A feature or function.

"System operations that process PII." [5]

"Enabling the processing of PII or events without association to individuals or devices beyond the operational requirements of the system." [5]

The ability for an IoT device to communicate directly with people.

Capabilities which enable interactions involving IoT devices (e.g., device-to-device communications, human-to-device communications). The types of interface capabilities are application, human user, and network.

The ability to interface with a communication network for the purpose of communicating data to or from an IoT device. A network interface capability allows a device to be connected to and use a communication network. Every IoT device has at least one network interface capability and may have more than one.

"Information that can be used to distinguish or trace an individual's identity, either alone or when combined with other information that is linked or linkable to a specific individual." [8]

An operation or set of operations performed upon PII that can include, but is not limited to, the collection, retention, logging, generation, transformation, use, disclosure, transfer, and disposal of PII.

A cybersecurity or privacy capability an organization selects, acquires, and deploys itself; any capability that is not pre-market.

A cybersecurity or privacy capability built into an IoT device. Pre-market capabilities are integrated into IoT devices by the manufacturer or vendor before they are shipped to customer organizations.

A system operation that processes PII through the information lifecycle and as a side effect causes individuals to experience some type of problem(s). 
Risk

Sensing Capability

Supporting Capabilities

Transducer Capabilities
"A measure of the extent to which an entity is threatened by a potential circumstance or event, and typically is a function of: (i) the adverse impact, or magnitude of harm, that would arise if the circumstance or event occurs; and (ii) the likelihood of occurrence." [4]

The ability to provide an observation of an aspect of the physical world in the form of measurement data.

Capabilities that provide functionality that supports the other IoT capabilities. Examples of supporting capabilities are device management, cybersecurity, and privacy capabilities.

Capabilities that provide the ability for computing devices to interact directly with physical entities of interest. The two types of transducer capabilities are sensing and actuating. 


\section{Appendix D-References}

[1] Newhouse W, Keith S, Scribner B, Witte G (2017) National Initiative for Cybersecurity Education (NICE) Cybersecurity Workforce Framework. (National Institute of Standards and Technology, Gaithersburg, MD), NIST Special Publication (SP) 800-181. https://doi.org/10.6028/NIST.SP.800-181

[2] Simmon E (forthcoming) A Model for the Internet of Things (IoT). (National Institute of Standards and Technology, Gaithersburg, MD).

[3] Stouffer K, Pillitteri V, Lightman S, Abrams M, Hahn A (2015) Guide to Industrial Control Systems (ICS) Security. (National Institute of Standards and Technology, Gaithersburg, MD), NIST Special Publication (SP) 800-82, Rev. 2. https://doi.org/10.6028/NIST.SP.800-82r2

[4] Joint Task Force (2018) Risk Management Framework for Information Systems and Organizations: A System Life Cycle Approach for Security and Privacy. (National Institute of Standards and Technology, Gaithersburg, MD), NIST Special Publication (SP) 800-37, Rev. 2. https://doi.org/10.6028/NIST.SP.800-37r2

[5] Brooks S, Garcia M, Lefkovitz N, Lightman S, Nadeau E (2017) An Introduction to Privacy Engineering and Risk Management in Federal Systems. (National Institute of Standards and Technology, Gaithersburg, MD), NIST Interagency or Internal Report (IR) 8062. https://doi.org/10.6028/NIST.IR.8062

[6] National Institute of Standards and Technology (2018) Framework for Improving Critical Infrastructure Cybersecurity, Version 1.1. (National Institute of Standards and Technology, Gaithersburg, MD). https://doi.org/10.6028/NIST.CSWP.04162018

[7] Joint Task Force (2017) Security and Privacy Controls for Information Systems and Organizations. (National Institute of Standards and Technology, Gaithersburg, MD), Draft NIST Special Publication (SP) 800-53, Rev. 5. https://csrc.nist.gov/publications/detail/sp/800-53/rev-5/draft

[8] Office of Management and Budget (2016) Managing Information as a Strategic Resource. (Office of Management and Budget (OMB), Washington, DC), OMB Circular No. A-130. https://www.whitehouse.gov/sites/whitehouse.gov/files/omb/circulars/A130/a130revise d.pdf 